\title{
PISMO BEACH PUBLIC ART PROGRAM
}

\author{
A Project \\ presented to \\ the Faculty of California Polytechnic State University, \\ San Luis Obispo
}

\author{
In Partial Fulfillment \\ of the Requirements for the Degree \\ Master of City and Regional Planning
}

by

Garrett Tyler Norman

May 2014 
(C) 2014

Garrett Tyler Norman

ALL RIGHTS RESERVED 


\section{COMMITTEE MEMBERSHIP}

TITLE:

AUTHOR:

DATE SUBMITTED:

COMMITTEE CHAIR:

COMMITTEE MEMBER:

COMMITTEE MEMBER:
Pismo Beach Public Art Program

Garrett Tyler Norman

May 2014
Umut Toker, PhD

Associate Professor of City and Regional

Planning

William Siembieda, PhD

Professor of City and Regional Planning

Carolyn Johnson, Planning Manager

City of Pismo Beach 


\section{ABSTRACT \\ Pismo Beach Public Art Program \\ Garrett Tyler Norman}

Public art plays a significant role in communities around the world. It embodies a close relationship between the artist, the space in which it's being exhibited, and the public. The development of this project examined various literary sources that demonstrated the importance of public art and how cities, artists, and community members may benefit from the incorporation of public art. This project included the framework for development of a Public Art Program for the City of Pismo Beach, California, which outlined the critical steps of a planning process and implementation of the program. 


\section{ACKNOWLEDGMENTS}

I would like to thank the Department of City and Regional Planning at California Polytechnic State University for their support in the achievement of this project, specifically Umut Toker who served as the advising chair and William Siembieda who served as a member of the committee. I would like to thank the City of Pismo Beach for their dedication in the success of this project, specifically Carolyn Johnson, Planning Manager, who also served as a member of the committee. Lastly, it is greatly appreciated for the City's Parks, Recreation and Beautification Commission members, Ron Rodriguez, Laurie Quigley Saldana, Kevin Kreowski, Sandra Gore Nielsen, and Andrew Jones for their participation and commitment to the Public Art Program. 
LIST OF TABLES

CHAPTER

I. INTRODUCTION .............................................

II. LITERATURE REVIEW ................................... 3

Historical Context ......................................... 3

Placemaking and Public Art ............................. $\quad 5$

Placemaking Techniques ........................ $\quad 5$

Collaboration .................................... 7

Benefits .................................................... 8

Economic ......................................... 8

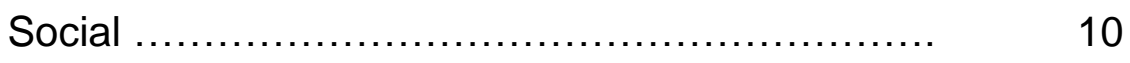

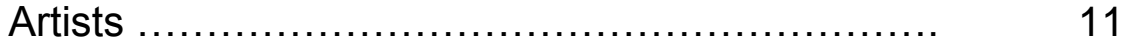

Funding Opportunities ................................... 12

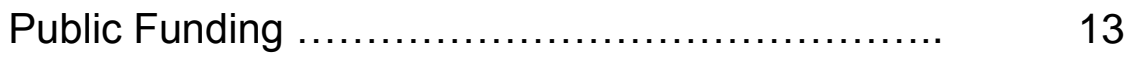

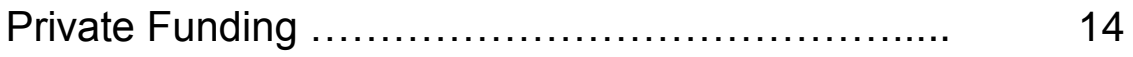

Grant Opportunities .............................. 15

Forms of Public Art ...................................... 17

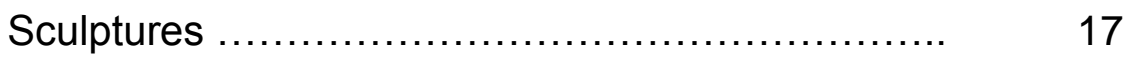

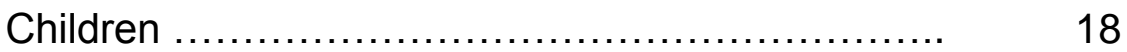


Murals

Nightlife

Interactive

Public Works

Informational

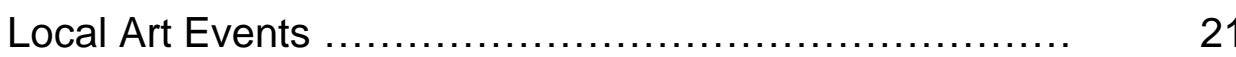

III. PROJECT DESCRIPTION AND RATIONALE ...................... 23

IV. METHODOLOGY ................................................. 24

Opportunities and Constraints ............................ 26

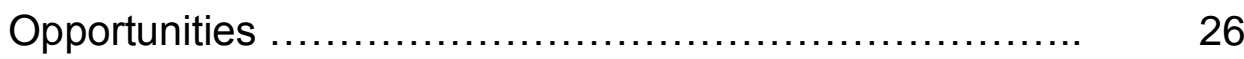

Pismo Beach Car Show ............................ $\quad 26$

Jazz Festival ...................................... $\quad 26$

Pacific Ocean ..................................... $\quad 27$

Pismo Pier and Promenade .......................... $\quad 27$

Incorporation into Current Projects .................. $\quad 27$

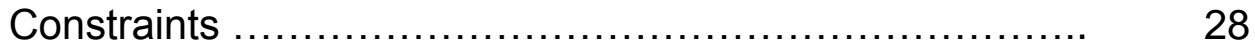

The Alternative Method Approach ......................... 28

Alternative 1: Keep the Status Quo .................. $\quad 28$

Alternative 2: Creation of Public Art Program ........ $\quad 29$

Subsequent Alternatives ............................ 31

Finding the Optimal Alternative ...................... 31

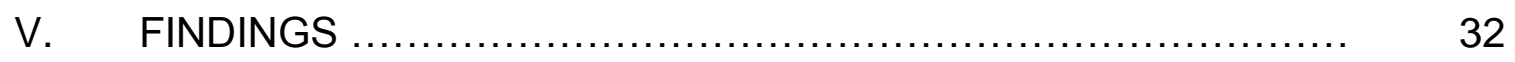

PRBC Hearings .......................................... 32 


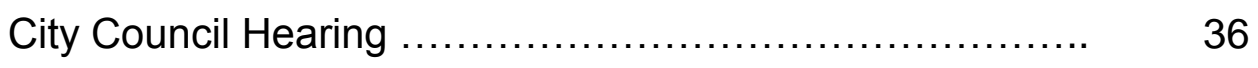

Public Outreach ........................................ $\quad 37$

Case Study Review ..................................... $\quad 40$

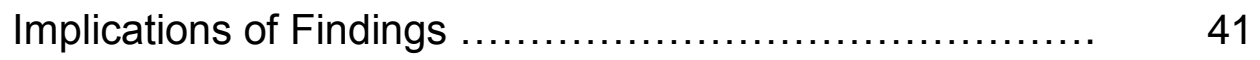

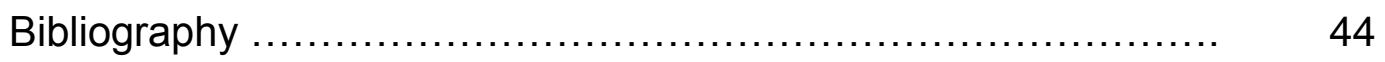

\section{APPENDICES}

A. PISMO BEACH PUBLIC ART PROGRAM .................. 47

B. LOCAL ART BROCHURE ................................ 60 


\section{LIST OF TABLES}

Table

Page

1. Commercial Project In-Lieu Fee ............................ 35

2. Multi-Family Project In-Lieu Fee ................................... 35

3. Key Locations for Public Art .............................. 40 


\section{LIST OF FIGURES}

$\begin{array}{lll}\text { Figure } & \text { Page }\end{array}$

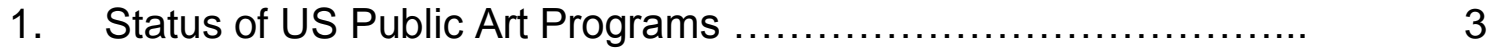

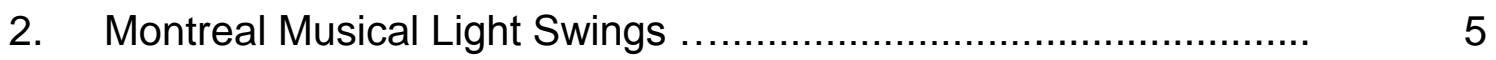

3. Washington, DC's AIDS Memorial Quilt ........................ 10

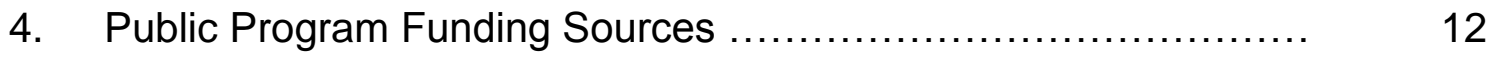

5. Minneapolis' Spoonbridge and Cherry $\ldots \ldots \ldots \ldots \ldots \ldots \ldots \ldots \ldots \ldots \ldots \ldots \ldots \ldots \ldots \ldots$

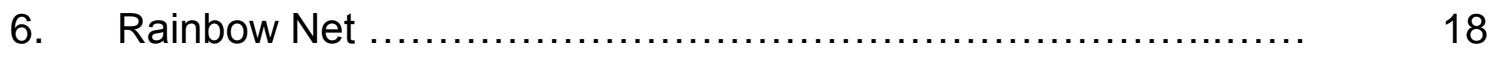

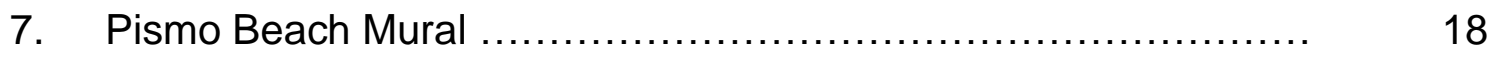

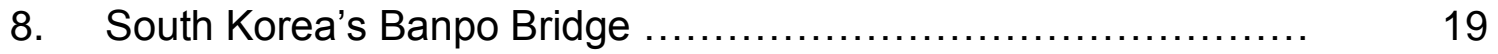

9. New Orlean's "Before I die..." ............................... 20

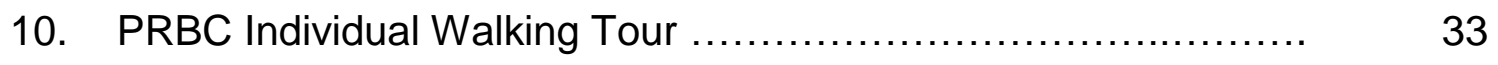

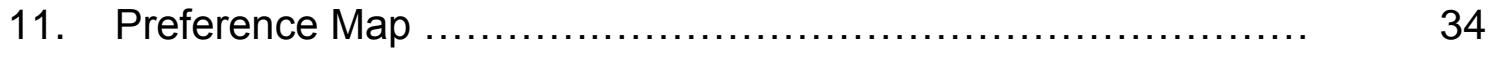

12. Participation in Outreach Exercise .......................... 37

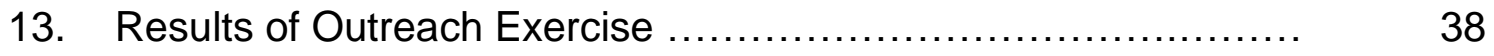




\section{CHAPTER 1}

Introduction

City beautification is often associated with the historical movement that occurred in the beginning of the $20^{\text {th }}$ Century as an effort to beautify cities in the form of iconic government institutions. Today, this very concept is of similar value, but exercised in a myriad of urban forms. One increasingly common form is through the operation of a public art program. Public art is able to add character to urban and natural spaces through small and large exhibits of artwork that is observed by the public. These artworks are most commonly understood in the form of murals and sculptures, but more recently artists have introduced public art to a new realm of creativity through interactive and illuminated pieces.

The City of Pismo Beach is an ideal location for unique artwork. The City is located on the central coast of California in San Luis Obispo County, halfway between San Francisco and Los Angeles. In addition, the historic El Camino Real and Highway 1 bisect the city. Pismo Beach is a major destination point from all places around California and across the United States. Being a tourist destination and having two major routes running through it, there is a great amount of foot and vehicular traffic. As a result of the City's location and popularity, public art projects can be experienced by many.

Public art builds a unique sense of place. A formal program for Pismo Breach can complement the existing "Classic California" character the City notably offers. Not only can Pismo Beach utilize a public art program for its additional charm, but also economic vitality. Public art can be very inspirational 
and fun, making it an economic generator from art enthusiasts and the general public. Pismo Beach has the opportunity to increase its economic base by building off the existing strong artistic culture in San Luis Obispo County and becoming a distinct hub for exhibits. This notion expands its attractiveness as a destination interest in beautiful surroundings, physical environment, and its geographical location in California. Ultimately, the City of Pismo Beach would greatly benefit from a Public Art Program.

The overall goal of this project is to create a publicly operated Public Art Program through the City of Pismo Beach. The Program will outline all the necessary components associated with a public art program including administration, funding mechanisms, artwork review, and implementation into the public realm. The Program will be a livable document with the opportunity to build and grow as operationally deemed necessary. 


\section{CHAPTER 2}

\section{Literature Review}

According to Becker (2004), roughly eighty-one percent of public art programs are operated through a public agency (Figure 1). Some of these are operated by cultural affairs, art

commissions, or planning and

other departments (Becker, 2004,

- Public Sector Programs

p. 2). Since public art is a

community based ideology and

employee staff time may be

Private Programs

limited, many public sector

programs will contract to outside

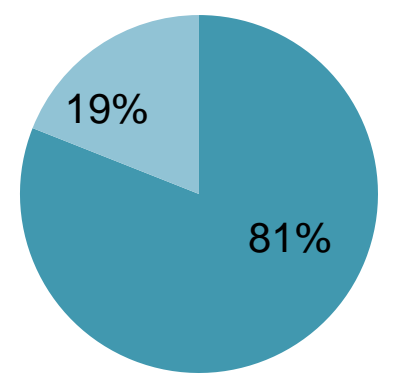

Figure 1 - Status of US Public Art Programs Recreated from Becker (2004)

vendors like planning consultants, photographers, public relations specialists,

and other design inspired professionals to help with the public art process. Public art programs are becoming increasingly important to many private and public agencies due to its recent popularity in the last four decades.

Historical Context

Early European democracies are cherished for their successful undertakings of establishing a social importance to place. The agora of Athens in Greece is an early $10^{\text {th }}$ to $8^{\text {th }}$ Century BC example that epitomizes social order in the form of a central market through shared space. "Accounts of the agora of Athens refer to... the place where city life is visible and audible, the place of transactions of both good and idea, and where artefacts are made..." (Miles, 
1997, p. 3). This notion corresponds to more recent efforts of placemaking, where professionals reinvent this notion of a shared common space that fosters social activities.

In addition to the early European social order to space, the City Beautiful Movement captures an early American effort. This movement was a reaction from the disorganized "slum cities" in America after the rapid industrialization in the late $19^{\text {th }}$ and early $20^{\text {th }}$ centuries. Hall (2002) notes Daniel Burnham (1890s1910s) was the forefather of this movement where he envisioned cities becoming beautiful by taking pride in America's civic buildings through the design of grand boulevards that gave prominence to these institutions. Burnham's ideas came from European Capitals, like Haussmann's reconstruction of Paris, which focused on boulevards and promenades. In response to the rapid industrialization of America, Daniel Burnham's Chicago plan of 1909 became the most influential movement in planning history and beautification.

Burnham truly believed one could fix the ills of urban centers by making them beautiful; the chaotic city was a result of too much rapid growth and a too rich mixture of nationalities in which could be solved by giving order to in the form of new thoroughfares, slum elimination and park extensions (Hall, p. 193, 2002). Public art can be seen as a link to the new century modern of the grand visions from the early $20^{\text {th }}$ century to the smaller scale of beautification in today's planning efforts. 


\section{Placemaking and Public Art}

Sameness of space; the commercial strip, main street, the industrial center, highways leading to the airport strip. This has become the American melancholy since World War II (Fleming \& Tscharner, 1987, p. 1). Placemakers are considering this phenomenon placelessness, in which to combat this urban ill is to strategize techniques that connect people to particular spaces or environments (Fleming \& Tscharner, 1987, p. 1). One strategy to influence this connection is through the incorporation of public art. Subsequently, the art of placemaking has been of increasing attention to urban designers, architects and planners. Some determine "figurative illusions evoke a lively conversation" or the "focus on the memory of space for a design element" are the ways in which to instill a sense of place (Fleming \& Tscharner, 1987, p. 3). However, as these two concepts are illustratively successful in the preservation of our environment, the concern for consideration to new environments are pressured. Fortunately, these techniques are fully capable to foster more than enough meaning to warrant future care and perhaps eventual preservation (Fleming \& Tscharner, 1987, p. 5).

Placemaking Techniques

Placemaking stems to four simple techniques or solutions that stimulate a space; direction, connection, orientation, and animation. First, direction involves the idea to create a path of space, meaning a

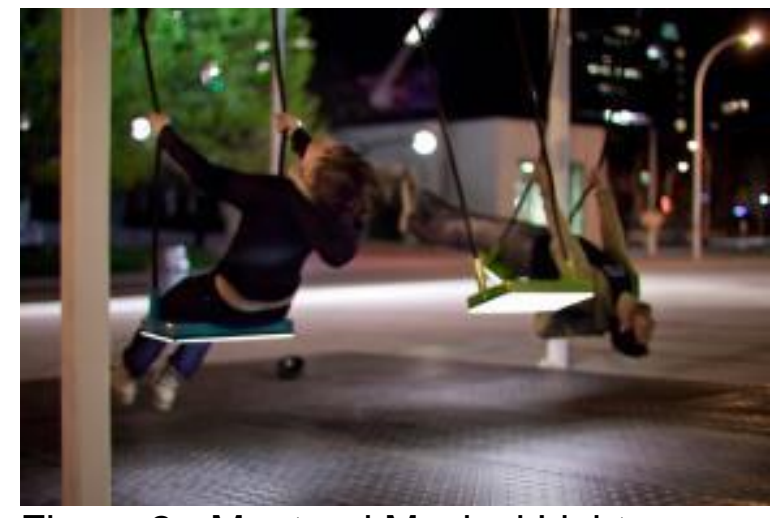

Figure 2 - Montreal Musical Light Swings 
vivid navigation through the space where "( $t$ )he eye can be moved artfully from object to connecting object, forging a trail of little encounters..." (Fleming \& Tscharner, 1987, p. 8). Second, placemakers try to establish the connection of space through a multitude of meanings; for instance, combining several contrasting artworks in a space that represent the meaningful occurrences of a few historical milestones to that particular place. Next, and most commonly utilized, are spaces simply identified by having strategic orientation placed upon it (Fleming \& Tscharner, 1987, p. 1). An example of this can be best identified as a public plaza or park that has the seating located in one area, a fountain as a focal point and grass and trees for picnics. Lastly, and most excitingly, spaces can invite the opportunity to come alive in the form of animation. This can be seen as large exhibits, like the Bellagio water feature on the Las Vegas strip, or smaller displays, like the musical light swings bus stop in Montreal, Canada (Figure 2). In essence, these spaces attract large crowds who are inspired to participate in its animated feature.

Fleming and Tscharner (1987) suggest the most common design elements exercised in placemaking are wrought iron fencing, bollards and decorated benches. These elements ultimately reinforce the attractiveness of a space, but lack in their uniqueness, whereas when the four techniquesdirection, connection, orientation, animation—are utilized, opportunities to establish unique character are invited. 


\section{Collaboration}

Successful public art projects are the result of a collaborative effort from several public and private entities. Specifically those standalone public art agencies, like Public Art San Antonio in Texas, must explore their many options to incorporate public art within the urban fabric. This is primarily because, "(u)nless public-art agencies work in concert with planning offices, historical commissions, local officials, and departments of public works, they fight an uphill battle" (Fleming, 2007, p. 289). The first essential requirement is communication. Public art agencies must communicate, especially if there are several within neighboring jurisdictions, for example a county and a city who are both trying to formulate a large piece of artwork. Fleming (2007) states, it is typical bureaucratic behavior for two agencies to not work and correspond together on a project. However, in order to achieve a great place, communication is required for asking important questions to best learn about a particular site, like its historical milestones. Therefore, the place suddenly becomes a collaborative effort.

Fortunately, public art can leverage itself through the regular maintenance requirements of cities in the form of infrastructure, current planning projects, the array of politics, and urban design opportunities. During these ongoing maintenances, public art can always be presented for a potential implementation project. Nonetheless, these potential projects will only present themselves if all required parties are equally informed of its potential. As a result, Fleming (2007) 
suggests public art is best implemented when streamlined like a planning process.

Benefits

Public art produces positive externalities that result in benefits for the citizens, visitors and community overall. The three most projected benefits are economic vitality, social communication, and a more vibrant artist community. Public art programs are able to boost a local economy through a multitude of ways, but most commonly introduce tourism opportunities and potential redevelopment projects geared towards the arts. The social benefits can be countless as the opportunity to express ethnic and historical happenings of the community in the form of public art ascend. Furthermore, the attraction of a diverse audience to these forms of public art can create the happenstance to engage in conversation about the subject artwork, emphasizing placemaking characteristics. Lastly, artists play a major role in public art by acting as dual beneficiaries. First, they benefit from the program through potential solicitation of their artwork and second, they contribute to the program by hosting artist venues which can promote the existing artwork throughout the city.

\section{Economic}

Public art can be used as an instrument for municipalities as an economic development strategy. For example, communities with a strong sense of artistic culture allow for venues and studio tours in which visitors from around the world are inspired to explore these artwork centers of commerce. Santa Fe, New Mexico and Sedona, Arizona are prime examples of such communities. 
However, this is a major debate in the discussions of public art's primary function; the argument is discussed between intrinsic versus instrumental. By definition, intrinsic describes the aesthetic value of any artwork as an expression of the artist's individuality. In conjunction, instrumental artwork relates to art acting in the form of a value such as tourism, education, job creation, and an increase in property values. Beyond the solitary purpose of public art's function, many local agencies are quickly realizing the potential economic benefits of both sides of the argument.

Public art is a tool for economic development strategies through the incorporation of art exhibits or local displays from artists. This can help stimulate the economy through generating tourism which helps support sales tax and transient occupancy tax. Additionally, this stimulates the local revenue boost for the artists as well. For instance, local artists have the opportunity to display their own artwork at an exhibit or display show, which may have been generated by the public art program itself, where purchasers are able to become more familiar with an artist's particular work, eventually leading to more sales. For example, local governments can cater towards this type of phenomena through the redevelopment of underutilized spaces. In North Adams, Massachusetts, an unused building on a 13-acre site was turned into a space for large art installations. This converted building has become the Massachusetts Museum of Contemporary Art, where "the once standing factory has now been able to house creative design businesses like Web design firms.... (t)he museum has attracted 
100,000 visitors, contributed $\$ 15$ million to the local economy, and increased local property values by $\$ 14$ million" (Green, 2011).

Ultimately, public art can stimulate the local economy in multiple ways by utilizing or commissioning local artists to either create a piece of public art for the city in which they live, or having the opportunity to participate in local art festivals.

\section{Social}

Public art creates endeavors for jurisdictions to form a sense of place for their citizens and visitors through the strategic location of public art in their gateways to a new location, high people capacity corridors, downtown, along trail systems, or in parks. If placed in a successful place, public art has the opportunity to become a memorable moment in time. When thinking about memorable places, a number of icons come to mind. For example, memorable public art can be captured in pictures, postcards and in family photo albums. The iconic Bean in Chicago, the St. Louis Arch, or the Sundial Bridge in Redding are great examples. Relatively, "(p)ublic art activates the imagination and encourages people to pay attention and perceive more deeply the environment they occupy... [it] stimulates learning and thought about art and society, about our interconnected lives, and about the social sphere as a whole. Public art is uniquely accessible and enables people to experience art in the course of daily life, outside of

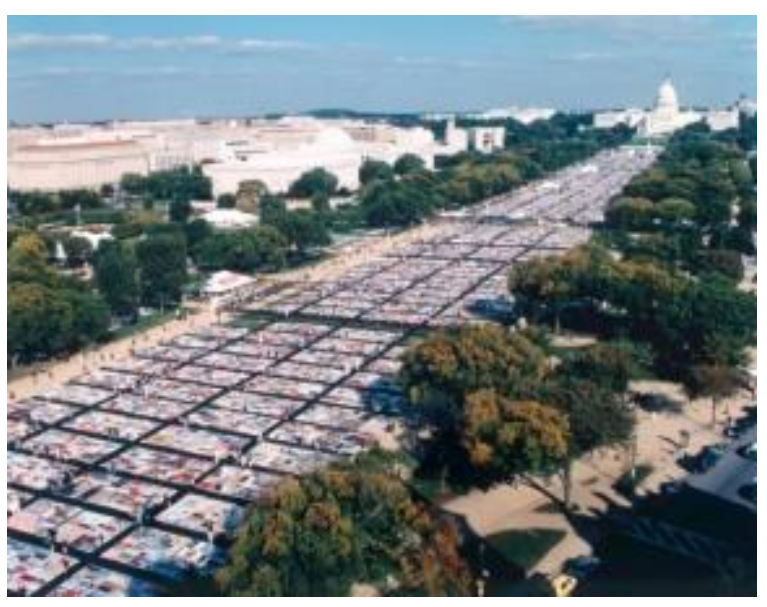

Figure 3 - Washington, DC's AIDS Memorial Quilt 
museums or other cultural institutions" (Public Art Network Council [PANC], n.d.).

In addition to contributing to memorable moments, public art has the opportunity to express awareness about societal ills like prejudices, violence, and environmental degradation. Becker (2004) symbolizes the AIDS Memorial Quilt, in Washington, DC, as an example (Figure 3). The quilt features over 70,000 individually crafted quilts to raise awareness of the AIDS epidemic in order to increase research and educational efforts (Becker, 2004, p. 7). The key component to generating research and educational leverage was primarily from its media attention and sheer size.

\section{Artists}

Beyond the customary aesthetic benefits of displaying works of art for the public's interest, local artists can make valuable contributions. It is essential to include the local artist community into the visioning process of planning public spaces. Artists must hold equal value to planners, engineers, designers, stakeholders, and elected officials as their knowledge and expertise in the art realm is more significant. Artists are able to provide a unique characteristic to the idea, site, social construct, and design of the piece of artwork. Additionally, artists can act as a liaison to the community, providing educational opportunities of its importance, or advocating for its significance in a more challenged political environment (Becker 2004);

The effort of creating art for public space is not solitary: the public art process asks the artist to share [their] creative point of view and approach to art-making, and to collaborate with others throughout its development. 
In consequence, the work can reverberate throughout the community, thereby encouraging a sense of shared ownership and collective affiliation.

(Becker, 2004)

Public art refines the built environment and enlivens public

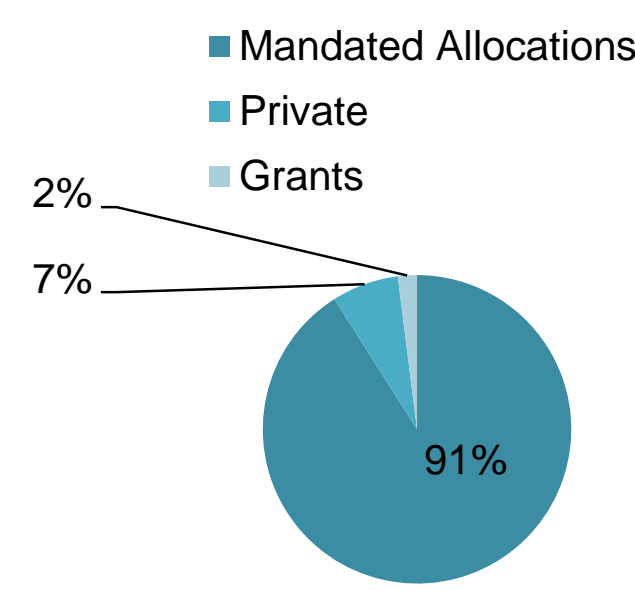

Figure 4 - Public Program Funding Sources Recreated from Becker (2004)

spaces. It provides a thin crossing between past, present and future, between disciplines, and between ideas. Only those most successful projects approach the situation in a collaborative approach where consensus building is utilized for the best output possible.

\section{Funding Opportunities}

Public art in the United States has exponentially grown in the last decade. Becker (2004) notes this growth has been largely influenced by local and regional public agencies that have begun commissioning public art through a formal program. Statistically profound, "( $t$ )he average budget of the nation's public art programs grew 27.4 percent to $\$ 779,968$ during 2001, [where] (i)n fact, the average public art budget nearly doubled between 1998 and 2001, increasing an average of 23.5 percent annually" (Becker, 2004, p. 4). In 2003, it was estimated that the United States spent a total of $\$ 150$ million on public art. 
For public agencies, determining a mechanism to fund the solicitation and maintenance of public art can be a challenge. A government operated public art program may consider generating revenue from public sources, funds that are part of the local agencies revenue source like its capital improvement and general fund, private sources that are most commonly associated with funds accumulated by a surcharge on new development, or a combination approach of both private and public funding. According to Becker (2004) "(m)ost public art programs are funded by a 'percent-for-art' strategy_first used in Philadelphia in 1959-in which a small portion of capital improvement funds are allocated for acquiring or commissioning artwork" (p. 4). In recent decades, with increasing popularity, a variety of funding mechanisms have been utilized to support public art. These methods include, but are not limited to, “....annual appropriation, departmental allocation, hotel/motel tax, sales tax, tax increment financing,.. foundation grants or private gifts, corporate sponsorship, benefit auctions, and fundraising events" (Becker, 2004, p. 4). Figure 4 illustrates the percentage breakdown of the three primary funding sources used for the commissioning of public art in government operated programs.

\section{Public Funding}

A percent-for-art ordinance is the most commonly utilized funding source for public art. The passing of a percent-for-art legislation requires a small percentage, usually .5 to 2 percent, of publicly funded capital improvement or general funds per year for the solicitation of public art. According to Project for Public Spaces, "(p)ercent-for-art ordinances guarantee a funding stream for 
public art projects regardless of what happens to city budgets or arts funding" (Project for Public Spaces [PFPS], n.d.). Additionally, most ordinances are conditioned to require the commission of public art on a yearly basis to guarantee a fixed yield of public art.

Utilizing a percent-for-art ordinance can have several benefits. First, the funds can be gathered from a range of city departments. This helps those cities where there is a large gap in revenue sources as certain departments may generate more than others during specific times of the year. Second, the ordinance becomes legally binding, therefore requiring obtainment of funds exclusively for public art purposes. Lastly, as seen in Atlanta, the ordinance could be constructed to allow for public art placement on the fringe of neighboring jurisdictions to allow for a more diversity in the placement of public art (PFPS, n.d.). This concept could be a great consideration to those jurisdictions, like Pismo Beach and Arroyo Grande, which have shared arterial streets that bring community members to large retail destinations in both jurisdictions.

\section{Private Funding}

In other instances, jurisdictions decide a private funding source for commissioning public art better fits their needs. Consequently, these programs have to become more creative in how they generate funding. One common strategy is to require a developer fee on new projects that encompass a large amount of square footage. A second way is by individually soliciting developer participation one project at a time. Project for Public Spaces recommends the solicitation of developer participation is crucial in the beginning stages. The 
public art program's staff should be well aware of the potential in the early stages, informing the developers during the visioning process of the project. Next, staff should determine a viable incentive for the developers:

...developers are often requested or required by cities to provide parking, a certain number or amount of coverage by street trees, curbs and sidewalks, etc. Public Art could be added to this list, or developers given the opportunity to include public art in a project as a way of meeting the requirement for providing these kinds of on-site amenities. Fees paid by developers, or requirements that developers provide more affordable housing or a park as part of a project, also could be set aside to fund works of public art. In Portland, OR, public art is acceptable as an alternative to meeting the city's requirements for ground floor windows (no blank walls at street level). (PFPS, n.d.)

Ultimately, developers are becoming increasingly favorable to developer fees and participating with incentive strategies because they are realizing the many benefits associated with public art. For example, "developers understand public art can improve employee and tenant working environments; (c)reate a unique look or landmark feature for the project; (d)emonstrate a larger civic commitment; and (t)ranslate into higher rents and a more desirable office location (PFPS, n.d.).

\section{Grant Opportunities}

In addition to a percent-for-art ordinance, development fee, or the sole petitioning for public art from developers, local and private agencies are able to 
apply for a series of grants from federal agencies. The National Endowment for the Arts (NEA) is the leading national agency in providing grant monies to selected participants. The Art in Public Places program, initiated in 1967 by the NEA, is the historical movement that shaped today's grant funding programs for public art. This grant served as a matching fund for community instigated public art projects, surprisingly receiving a significant amount of momentum in its early pilot stages (Beardsley, 1981, p. 6). Today, the NEA has become much more aggressive in its grant funding opportunities.

Their most common grant accompanying public art, Our Town, is given to applicants whose primary goal is to initiate a creative placemaking project. The grants typically range from $\$ 20,000$ to $\$ 200,000$ depending on the scale of the project (National Endowment for the Arts [NEFTA], 2013). Since inception four years ago, "(o)ur Town has provided $\$ 16$ million to support 190 projects in all 50 states and the District of Columbia. These projects are diverse in geographic distribution, number and types of partnerships, artistic discipline, and type of project. In [Fiscal Year] 2013 alone, 35 of the 59 grants supported projects in communities with populations under 100,000" (NEFTA, 2013).

Local government agencies have many successful strategies to help commission public artwork. It is these agencies that have the option to determine the most suitable strategy for funding. A progressive city that would like to acquire a significant amount of artwork may be more interested in a mandated program, like the percent-for-art ordinance that guarantees an annual yield of public art. Those jurisdictions that may be in a financial bind may choose 
competitive private funding sources through developer solicitation or grant opportunities. In any case, the outcome is a unique piece of public art that is visible to the public, where on private or public property. Forms of Public Art

Public art can be seen in many forms. Often times, public art is so unique, one may not consider it to be public art. Most commonly, artwork is illustrated in statues and murals, but more unique types include, nightlife oriented art that illuminates during evening hours, children oriented artwork that is either produced or generated towards children and interactive public art where people have the opportunity to play with or manipulate the artwork.

\section{Sculptures}

Sculptures are a very common form of public art. Sculptures can be manufactured using a variety of materials such as, wood, metal, ceramics and stone. Sculptures can also vary in size, ranging from a very large scale to a much smaller more personable scale. Each of them can elicit a different feeling in the viewer. Figure 5 is an example in Minneapolis, Minnesota that incorporates a water feature into the colossal sculpture of a cherry on the tip of a spoon. There are several places in Pismo Beach where sculptural public art could be located. Best places include the downtown, Pismo Boardwalk,

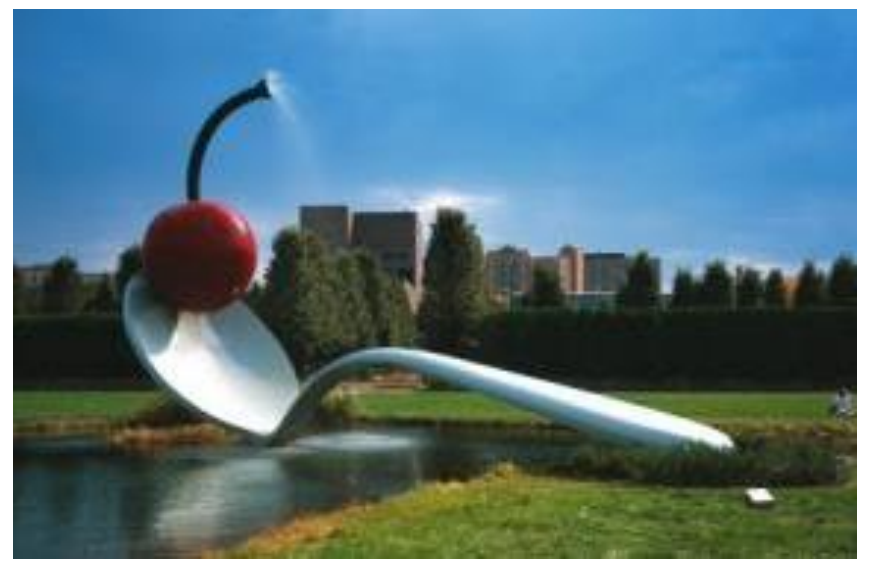

Figure 5 - Minneapolis' Spoonbridge and Cherry 
Chumash Park, and other locations throughout the City.

\section{Children}

Children oriented public art is located in areas that are close to elementary and middle schools, play grounds, parks, and other places in a

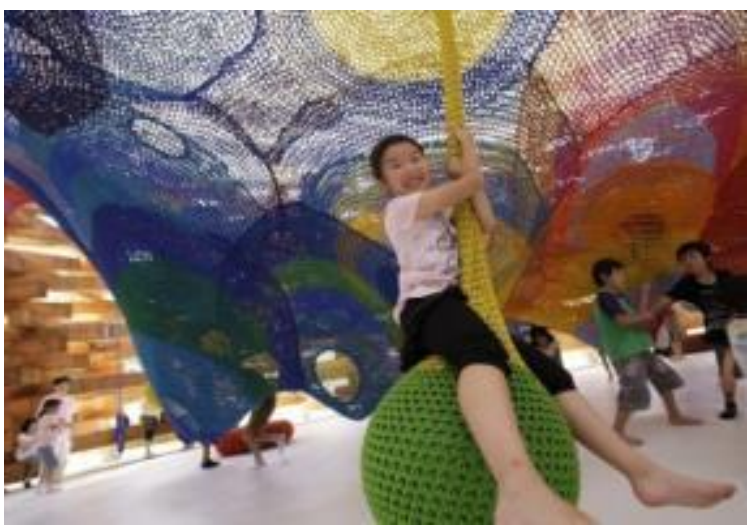

Figure 6 - Rainbow Net

community where children often congregate. In Pismo Beach great locations that would foster these types of artwork would be at the Shell Beach Elementary School, the downtown promenade and pier, and Spyglass Park. Figure 6 is an example of children oriented public art in Japan, where children are able to play on a life size net.

\section{Murals}

Murals are another commonly utilized form of public art. They can be vast in size, consuming an entire façade of a building, or much smaller, capturing only a portion of the building's façade. Pismo Beach currently has many murals located throughout city limits. These murals can mostly be found in the downtown area (as seen in Figure 7) and in Shell Beach, along Shell Beach Road. Murals have the

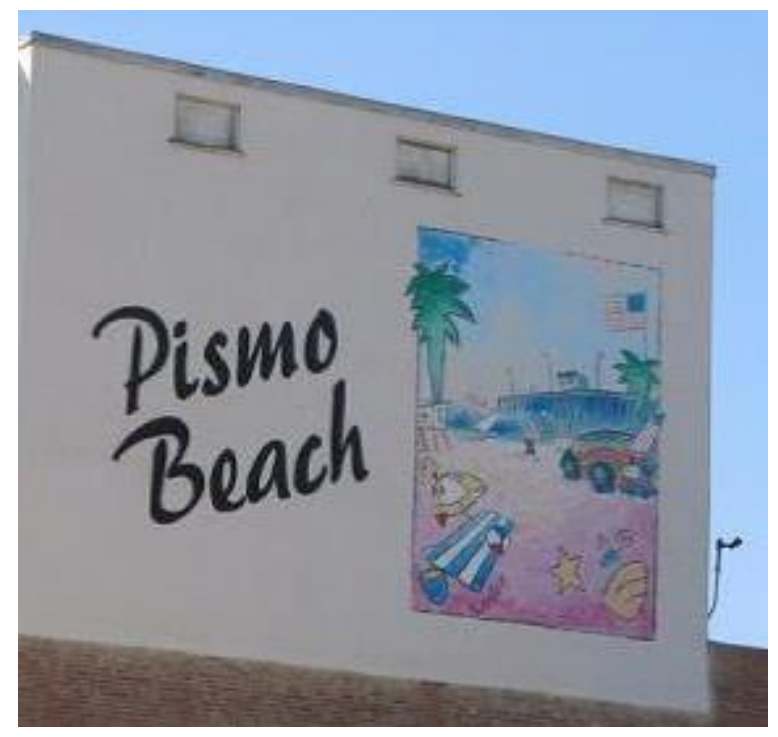

Figure 7 - Pismo Beach Mural 
opportunity to create a sense of place by having a large location based mural that depicts the unique character specific to that area. There are many more opportunity sites throughout Pismo Beach, where murals can capture Pismo Beach's "Classic California" character. Murals can also be pictured as a collage of mosaic tiles. Mosaic tiles require less maintenance, as painted murals fade, therefore requiring less funding for maintenance. This was one of the stressed concerns from the City of Pismo Beach Parks, Recreation and Beautification Commission.

\section{Nightlife}

Nightlife oriented public art is artwork that illuminates. These types of public art are uniquely located in areas where heavy foot traffic accumulates during the evening hours. This artwork is great for drawing people to specific locations for enjoyment. Figure 8 is a great example of nightlife oriented public art on the Banpo Bridge in Seoul, South Korea. Pismo Beach could have the potentiality to incorporate such unique pieces of artwork by utilizing their pier and other gathering places in the downtown. Pismo

Beach currently has

existing distinctive neon signs located in the downtown from the local business establishments. For example, there is a

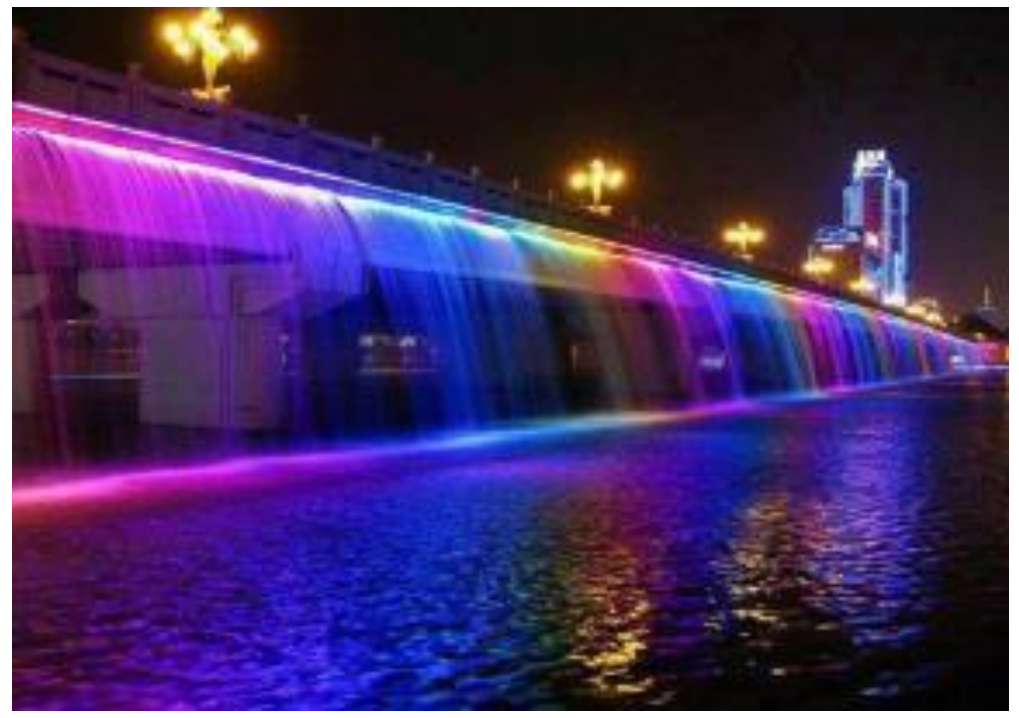

Figure 8 - South Korea's Banpo Bridge 
large "Pismo" sign that sits on top of the Pismo Beach Hotel. This is a large neon sign that also acts in providing a sense of place or wayfinding for downtown.

Interactive

Interactive public art is newly emerging form of artwork. The most

recognized form is in New Orleans, following the events of Hurricane Katrina.

Here, a large chalk board was posted on the side of an abandoned building

stating "Before I die I want to...." (Figure 9). This allowed bystanders to write in

their own unique response on the board, ultimately attracting viewers to see what everyone has written. This form of public art truly captivates the notion of placemaking as its visitors are specifically drawn towards its uniqueness with the hopes to interact with it. Many interactive pieces are also illuminated creating a dual attention grabber that let people watch as others participate in its activity.

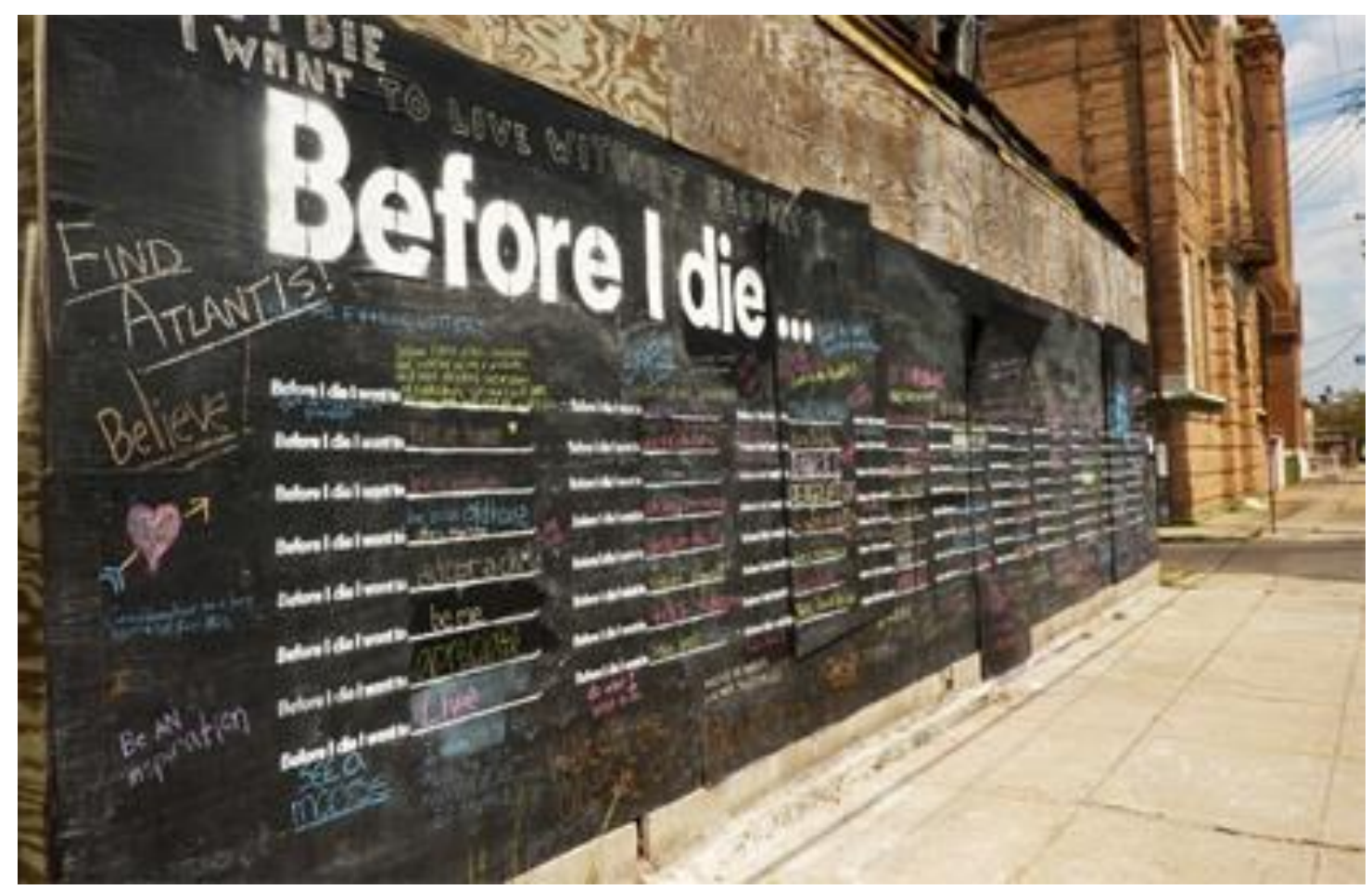

Figure 9 - New Orlean's "Before I die..." 


\section{Public Works}

Public works oriented art is generally city initiated on projects that are feasible for the inclusion of art. Most common examples are seen on pedestrian bridges, bus stops, bicycle racks, and the painting of utility boxes. One unique example that has emerged in California is the painting of lifeguard towers. Some cities, like Manhattan Beach, allow artists to create unique and colorful designs on their lifeguard towers. There are many other sites where the incorporation of such artwork can be located in Pismo Beach.

Informational

Informational public art is used to inform the general public of something unique or interesting about the area in which they are visiting. Informational public art can be seen in sculptures, benches, signs, and murals. In Pismo Beach, these types of artworks can be located at bluff-top lookouts, parks, and along sidewalks and trails. Such information could be provided regarding ancient setters, specifically the Chumash Indians, or marine wildlife in the area.

\section{Local Art Events}

There are several existing local art events in San Luis Obispo County and Pismo Beach that can contribute to and highlight the Public Art Program. ARTS Obispo is the regional arts council for San Luis Obispo County that supports the efforts of the local artists through a multitude of programs and events. The most popular festival they host is the Open Studios Art Tour. This exhibit tours over 230 locations throughout San Luis Obispo County, in which nine reside in Pismo Beach. The event is held annually over two weekends in October, where local 
residents and visitors can enjoy more than two-hundred of San Luis Obispo artists' studios.

Art in the Park @ Dinosaur Caves is a privately functioned Pismo Beach art festival that occurs the first Sunday of each month, through May and November, at Dinosaur Caves Park. The festival exhibits over one-hundred local artists and craftsman that specialize in an array of crafts such as, sculptures, paintings, textiles, jewelry, pottery, and many more. The festival is also home to family oriented activities, food, and music.

These local events could be a great resource for the Pismo Beach Public Art Program. The collaboration between the city government and private community organizations could coincide for the interests of the local community by providing insight on potential public art features and locations. Additionally, the festivals could incorporate a tour of public art located throughout the City as an added showcase for visitors and local artist contributions. 


\section{CHAPTER 3}

\section{Project Description and Rationale}

The idea to establish a public art program for the City of Pismo Beach has been an ongoing effort from city staff over the past ten years. On May 3, 2005 City Council adopted a Public Art Donation Program. The Pismo Beach Public Art Donation Program is a means by which an artist, or an individual or group commissioning an artist, may donate, give or bequeath public art to the City of Pismo Beach. Since adoption of this program, there have been no donations to date. However, there are existing pieces of public art in city limits that are located on private development, occurring mostly on a laissez-faire basis.

The itemization of a public art program has become part of City Council's agenda in 2010. For the 2010-2011 City Council Budget session, it was indicated as a long-term goal to develop a public art program for dedicating funding from new public and private projects. Furthermore, in 2011 a public art piece was incorporated into a Peoples' Self Help Housing project in the downtown. Lastly, in 2013, City Council listed within their long-term and short-term goals to implement a public art program.

With City Council's request to generate a formal public art program, the following project will include all the necessary components. However, in order to best construct a program for the City of Pismo Beach, it is important to complete a full analysis, discussed in Chapter Four. 


\section{CHAPTER 4}

\section{Methodology}

The City of Pismo Beach is a small coastal bedroom community of 7,721 residents (US Census Bureau, 2012). Although it is a smaller city in population size, in any moment of time there could be three times as many visitors due to its tourism attraction from the Central Valley and the San Fernando Valley. In order to best formulate a public art program for Pismo Beach, it was necessary to evaluate four California coastal cities with successful public art programs that are similar in size and attraction. These four city's public art programs were reviewed for precedence in order to formulate the final public art program for the City of Pismo Beach.

1. Dana Point, CA

2. Encinitas, $\mathrm{CA}$

3. Capitola, CA

4. Palm Springs, CA

Using the case study method, these cities were deeply analyzed on the successfulness of their program, any overarching similarities between the programs, the choice of funding, and the type of review mechanism for newly erected pieces of artwork. Additionally, it is vital to analyze these programs throughout their lifetime from point of adoption; a question to consider is what happened in the initial, middle, and mature stages of the program? In addition to the analysis of these four programs, it was informative to set up a personal interview with each lead staff member. This allowed for a more detailed analysis 
of the pros and cons of their program and what may be recommended for those initiating a new program. Also, it would be constructive to note the essential conditions for a public art program to grow.

Equally important to a professional's opinion and a full analysis of the case studies mentioned above, are those that live, work, and visit Pismo Beach. In order to grasp the opinion of a public art program from the general public, it is important to participate in community outreach events. One such event will occur in February 2014, regarding the City's Downtown Vision Plan. This workshop allows for fellow community members to provide essential input on the generation of a public art program.

The last approach will be monthly public hearings with the Parks, Recreation and Beautification Commission (PRBC). This commission is responsible for all beautification projects that occur in the City and will most likely have some authority in the review process of public art, post adoption of the program. It is critical to receive direction from the Commission on their comments and concerns in relation to public art in Pismo Beach. Subsequently, it will be necessary to produce monthly reports on the progress of the program, based on the direction provided by them from the prior hearing. The findings of these data collection approaches will help further develop the existing opportunities and constraints of public art in Pismo Beach and ultimately help the formation of the Public Art Program. 
Opportunities and Constraints

Before delving into the creation of plan documents, it was important to analyze the problem in which is being confronted. A quick exercise to understand the current situation in Pismo Beach is to do an analysis of the opportunities and constraints as they exist today in relation to a public art program.

\section{Opportunities}

Existing art related shows are shown as opportunities as they can contribute or enhance the Public Art Program.

\section{Pismo Beach Car Show}

Annually in the month of June, the City of Pismo Beach hosts a large classic car show. This event brings visitors from around the country to exhibit and discover classic cars. An event like this would be a great opportunity to incorporate public art exhibits. The combination of the two can foster a larger tourist crowd, boosting the City's economy and the Public Art Program.

\section{Jazz Festival}

Every October, the Basin Street Regulars host a "Jubilee by the Sea" jazz festival. This event draws in visitors from around the country to enjoy the art of jazz music. This would make a great contribution to a collective public art event. For example, the Jazz Festival could sponsor a temporary piece of public art to install in a nearby place to their event.

As mentioned in the literature review, there are two existing local art festivals; ARTS Obispo and Art in the Park @ Dinosaur Caves can help build the Public Art Program. 


\section{Pacific Ocean}

The Pacific Ocean should be seen as an opportunity to exhibit public art shows. Increasingly, there is a significant amount of technical illuminated public art shows that could be displayed on the shores of the Pacific Ocean. The ocean should not be seen as an inhibitor to public art displays.

Pismo Pier and Promenade

The Pismo Pier and Boardwalk are great areas to install temporary or permanent pieces of public art, in which the ocean could be used as a complimentary backdrop.

Incorporation into Current Projects

Currently, the City is undertaking a substantial visioning effort to strategically plan the future of their downtown. The incorporation of the Public Art Program or temporary locations where public art could be accommodated into the visioning and implementation efforts would be a benefit to the Public Art Program. The discussion of public art should be incorporated into the community outreach endeavors.

The multi acre ocean front Chapman Estate was bequeathed to the City of Pismo Beach by Clifford Chapman. The City will use the Estate for public and private benefits. Considering Mr. Chapman was a longtime supporter of local arts, it would be a great place to host local art events.

PG\&E storage yard: In consideration of temporary public art exhibits as an opportunity for the Public Art Program, artist would likely want to have a place to store their artwork. Working in collaboration with the PG\&E storage yard would 
be a great place for artists to work on their installations and store them until the next art event.

Constraints

The maintenance of public art is the largest and sole constraint for public art on a post implementation stage. However, with proper mechanisms in place, maintenance may no longer be seen as an immediate or long term constraint. The Pismo Beach Parks, Recreation and Beautification Commission have stressed the importance of developing a maintenance mechanism for public art. Without an efficient mechanism in place, the Public Art Program is simply impracticable as deteriorating public art becomes unattractive and eventually unfavorable to the public's perception. Additionally, the mechanism must be held to litigation standards as the required party responsible for the maintenance of the artwork could potentially walk away and not maintain the art when it is in disrepair. As a result, it is important a firm contract is in place.

The Alternative Method Approach

There is no single "one size fits all" approach to public art programs. As a result, there are several alternatives to consider. These alternatives are as follows:

Alternative 1: Keep the Status Quo

This alternative suggests the "do nothing" approach. Public art in the City would continue on a laissez-fair basis and any opportunity for bequeathing through the donation program. On a positive note, this would require less work by City Staff. A downside is the lack of guaranteeing an annual yield. Additionally, it 
would take more effort for the solicitation of public art from developers without an adopted ordinance.

Alternative 2: Creation of Public Art Program

This alternative is the generation of a formal public art program with mechanisms in place for providing funding to maintenance, the solicitation of artwork, and the review process.

Privately funded: With every new development over a certain amount of square feet, the developer is required to provide a piece of public art on site that is viewable in the public realm, meaning it will not be located within the interior of the project, but rather on the outside where the public can enjoy it.

Publicly funded: Each year the City of Pismo Beach can set aside a small percentage ( .5 to 1 percent) out of its General Fund to include in its Capital Improvement Plan for public art in eligible public works projects. The City can consider adding one percent to the transient occupancy tax (bed tax) to create funds for an annual project. The City can require a development fee (in-lieu-fee or percent-for-art ordinance) of developers. The fee could be between .5 to 2 percent of construction costs.

Combination funded: The most successful strategy could be a combination approach that includes both private and public funds to achieve the greatest yield in public art.

Review Process Option: A formal design review board of public art that includes a set of standards needs to be established. The following mechanism is a common approach: 
1. Submittal to Community Development Department: the proposal would be submitted to the Community Development Department where it will be checked for zoning, general plan accuracy and appropriateness, Building and Fire Code consistency, and American Disability Act (ADA) placement compliance.

2. Public Works and Risk Manager Review: Following Community Development/Planning Division review, the proposal would be forwarded to the Public Works Department and City Risk Manager for project review to: insure it would not create an undue risk or a safety problem; consider maintenance requirements; determine durability; identify any engineering concerns.

3. Parks, Recreation and Beautification Commission (PRBC) jury selection: Following the previous reviews, the Planning Division would notify the PRBC of a pending application. At this point, the artwork would be passed to a jury or committee that consists of one PRBC board member, one local artist, and two community residents.

4. PRBC Public Hearing: After a recommendation from the committee review, a duly noted public hearing will be heard by the PRBC to review the selected piece of artwork. Collectively this group will review the proposal and evaluate its appropriateness based on specific guidelines. The PRBC would then send a final approval recommendation to City Council. 
5. City Council Public Hearing: After PRBC approval and recommendation the City Council would be the final approving body of the selected artwork. Subsequent Alternatives

Other alternative options could be a mixture of the second alternative in which the program consists of only publicly funded projects, like in capital improvement projects, or privately funded projects, where the developer is required to solicit artwork and provide maintenance.

Finding the Optimal Alternative

The appropriate alternative for Pismo Beach has been decided after a series of Parks, Recreation and Beautification Commission meetings, discussions with various city departments and divisions, meetings with city officials, and the information received from interviews of city staff from the four reviewed programs—Dana Point, Encinitas, Capitola, Palm Springs—in conformance to the opportunities and constraints of Pismo Beach. 


\section{CHAPTER 5}

\section{Findings}

The planning process for the Public Art Program was fairly structured. The majority of the process occurred through monthly public hearings with the City's Parks, Recreation and Beautification Commission (PRBC). From conception in July of 2013, the Public Art Program became a monthly occurring topic. Throughout the fall academic quarter of 2013 , the majority of the PRBC hearings discussed theories and best practices of public art. It was initiated as a strategy to get the PRBC excited and motivated about the topic and how it could benefit the City of Pismo Beach. At the January 9, 2014 hearing, the Public Art Program began to jell into an actual program.

\section{PRBC Hearings}

The January hearing's discussion revolved around public art locations. The Commission came to consensus that it would be best to determine locations for public art downtown, as the City was currently undertaking a vision plan for their downtown. Based on direction given by the Commission, a walking tour map of the downtown was produced. The purpose of this exercise was for each Commissioner to pick a colored route, depicted on Figure 10, and individually walk the designated route. They were further instructed to site optimum locations for public art. Suggested locations in the instructions included building frontages, public right-of-ways that included sidewalks and parking lots, and other suitable places for public art. To accompany their suggestions, they were directed to take pictures. Based on the feedback given from the PRBC individual walking tour, a 


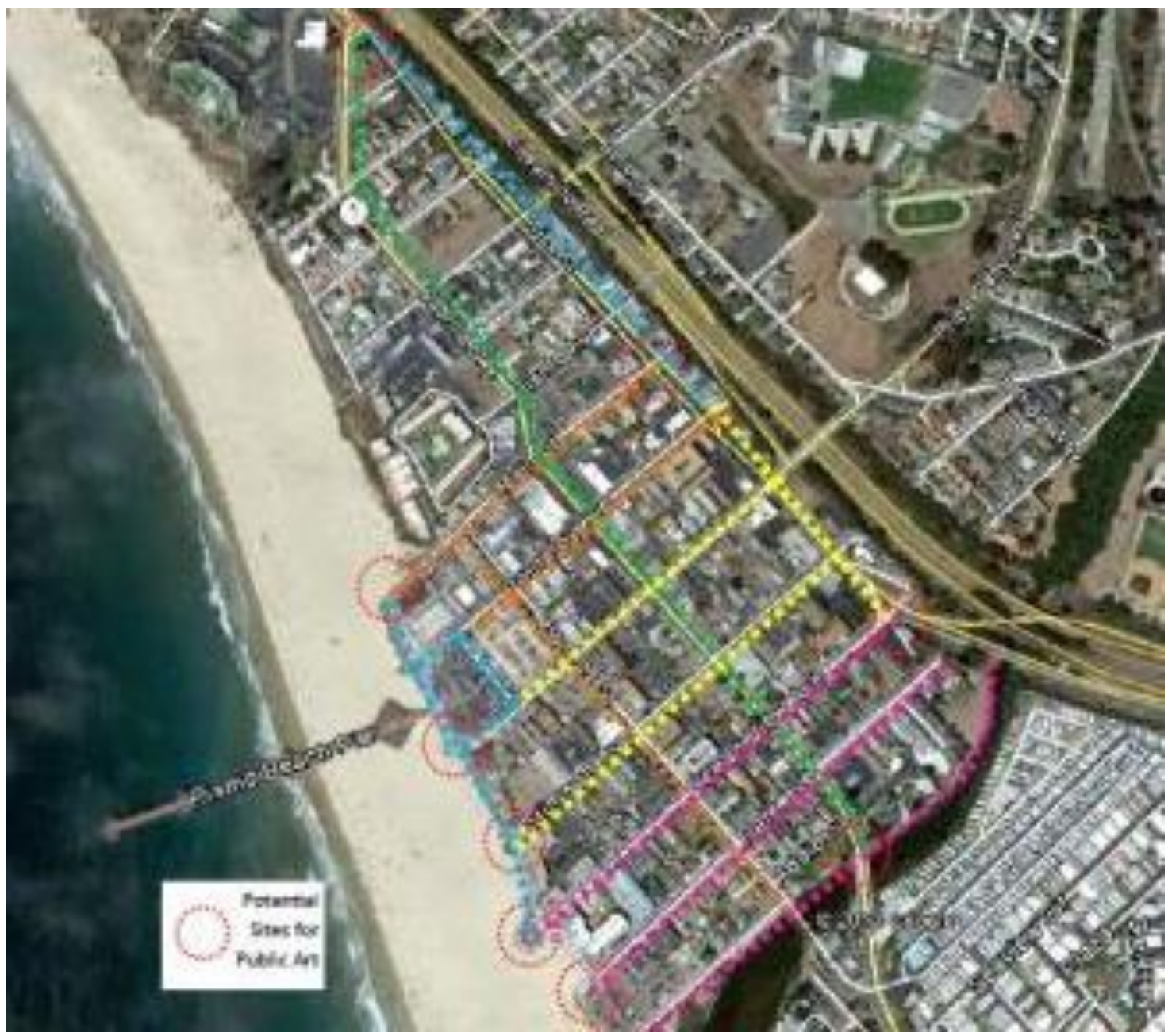

Figure 10 - PRBC Individual Walking Tour

map showing their suggestions was created. Figure 11 illustrates their combined suggestions for public art in downtown Pismo Beach. This map is known as a preference map, as it is the preference given from the current PRBC board members at that time. The February 2014 hearing was going to be held downtown, where the Commission and public could have the opportunity to announce their suggestions from the individual tour. Unfortunately, the meeting was canceled due to inclement weather. As a result, the continued discussion was set for the March 2014 hearing. 


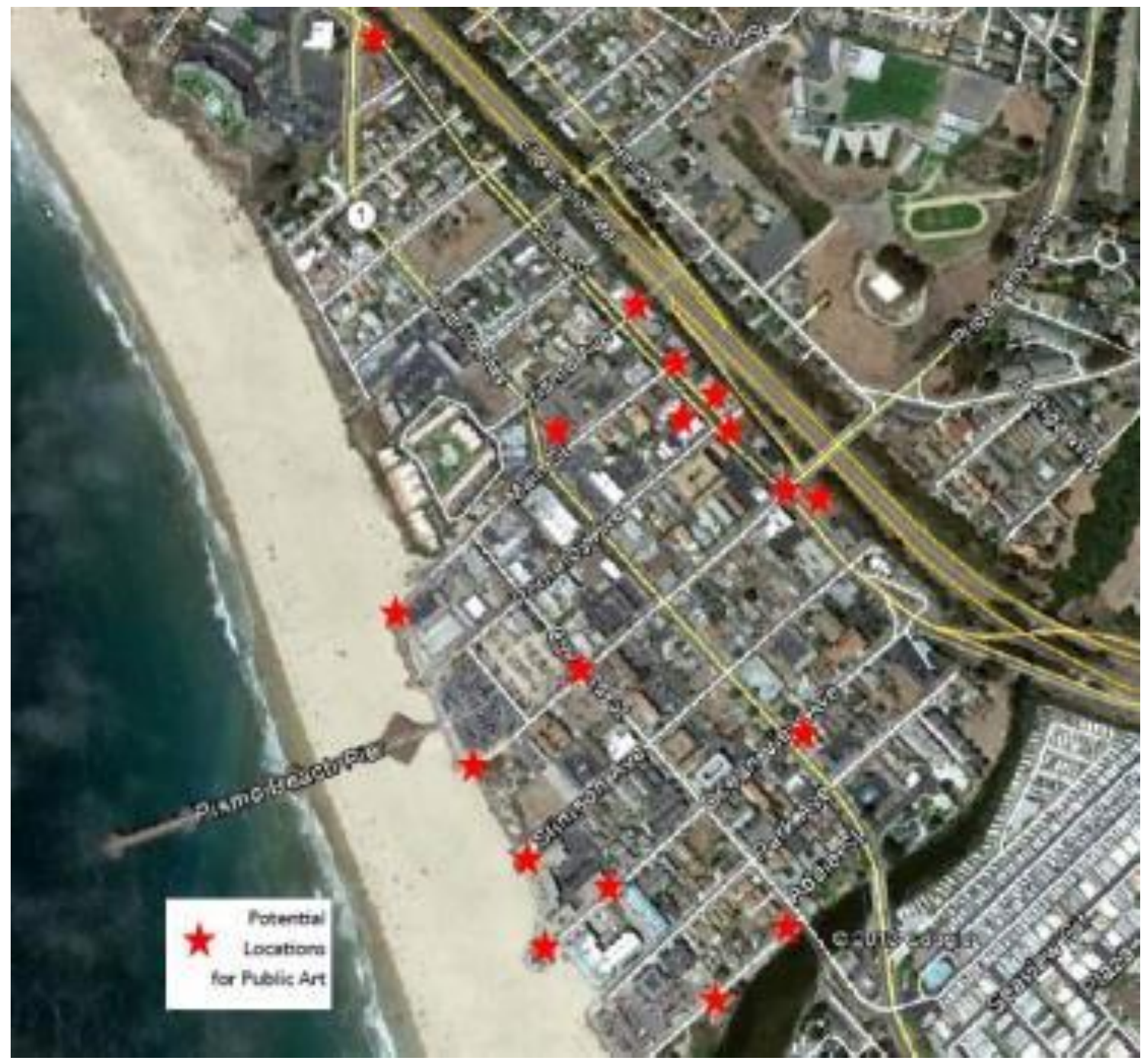

Figure 11 - Preference Map

At the March 6, 2014 hearing, the Commission shared their comments regarding the individual walking tours. As part of the report for the agenda, the preference map was discussed. In addition to the shared discussion of the walking tour, a more formal public art program was presented to them, discussing the necessary components on funding. The Commission reached consensus on the incorporation of some form of an exaction for commercial projects, but were also interested in potential revenue sources from existing city funds. In addition, the Commission stressed the concern for a review process 
and what it may look like. Given the direction and feedback from the March hearing, a revised public art program outline was developed.

During the hearing of April 3, 2014, an outline for the Public Art Program was presented, detailing methods for a review procedure and how much revenue the City could anticipate on a yearly basis with an impact fee in place. Tables 1 and 2 illustrate the amount of money that could be generated for commercial and multi-family projects with a building permit valuation threshold of $\$ 250,000$. The building permit valuation is a tool used by local governments to price the estimated cost of construction on a particular project. This allows a city to give an idea of what to charge in plan check fees and other building permit fees. The

Table 1 - Commercial Project In-Liu Fee

\begin{tabular}{|c|c|c|c|c|c|c|c|c|}
\hline \multicolumn{9}{|c|}{ Commercial Projects (New Construction \& Alterations) } \\
\hline $\begin{array}{l}\text { Calendar } \\
\text { Year }\end{array}$ & 2005 & 2006 & 2007 & 2008 & 2009 & $\begin{array}{c}2010 \\
\& 2011\end{array}$ & 2012 & 2013 \\
\hline $\begin{array}{c}\text { \# of } \\
\text { projects }\end{array}$ & 2 & 2 & 3 & 4 & 2 & 0 & 3 & 0 \\
\hline $\begin{array}{l}\text { Building } \\
\text { permit } \\
\text { valuation }\end{array}$ & $\begin{array}{c}358,750+ \\
900,000 \\
1,258,750\end{array}$ & $\begin{array}{c}617,255+ \\
629,871 \\
1,247,126\end{array}$ & $\begin{array}{c}255,000_{+} \\
750,000_{+} \\
\frac{200,000}{1,205,000}\end{array}$ & $\begin{array}{c}350,000+ \\
685,000+ \\
410,000+ \\
250,000 \\
1,695,000\end{array}$ & $\begin{array}{c}3,100,000+ \\
\frac{300,000}{3,300,000}\end{array}$ & 0 & $\begin{array}{c}250,000+ \\
1,000,000+ \\
\underline{800,000} \\
2,050,000\end{array}$ & 0 \\
\hline $1 \%$ & $\$ 12,587$ & $\$ 12,272$ & $\$ 12,050$ & $\$ 16,950$ & $\$ 33,000$ & 0 & $\$ 20,500$ & 0 \\
\hline
\end{tabular}

Table 2 - Multi-Family Project In-Liu Fee

\begin{tabular}{|c|c|c|c|c|c|c|c|c|}
\hline \multicolumn{9}{|c|}{ Multi-Family Projects (New Construction Only) } \\
\hline $\begin{array}{c}\text { Calendar } \\
\text { Year }\end{array}$ & 2005 & 2006 & 2007 & 2008 & 2009 & $\begin{array}{c}2010 \\
\& 2011\end{array}$ & 2012 & 2013 \\
\hline $\begin{array}{c}\text { \# of } \\
\text { projects }\end{array}$ & 5 & 4 & 4 & 1 & 3 & 1 & 0 & 1 \\
\hline $\begin{array}{c}\text { Building } \\
\text { permit } \\
\text { valuation }\end{array}$ & $\begin{array}{c}455,611+ \\
370,215+ \\
367,086+ \\
825,482+ \\
\frac{252,017}{2,270,411}\end{array}$ & $\begin{array}{c}338,908+ \\
338,908+ \\
994,463+ \\
\underline{374,672} \\
2,046,951\end{array}$ & $\begin{array}{c}933,903+ \\
1,928,975 \\
+ \\
\frac{450,269}{3,313,147}\end{array}$ & 587,597 & $\begin{array}{l}285,653+ \\
815,000+ \\
1,085,000 \\
2,185,653\end{array}$ & $1,652,370$ & 0 & $1,242,351$ \\
\hline $1 \%$ & $\$ 22,704$ & $\$ 20,469$ & $\$ 33,131$ & $\$ 5,875$ & $\$ 21,856$ & $\$ 16,523$ & 0 & $\$ 12,423$ \\
\hline
\end{tabular}


threshold of $\$ 250,000$ dollars was used based on examples seen in other municipalities, as well as an appropriate number for the City of Pismo Beach, based on the number of projects exceeding the threshold. These Tables provide a general estimate of how much money could be generated from 2005 to 2013 . It is important to note that commercial and multi-family projects were only chosen, as the Commission did not feel it would be responsible to put an exaction on single-family projects as individual property owners should not be taxed for public art, but rather developers who are building projects for the overall community's use should be, hence commercial and multi-family projects.

As depicted in Table 1, the majority of the funding was seen during the calendar year of 2009. The potential revenue stream from commercial projects grossed $\$ 33,000$, whereas in the years of 2010 and 2011 , there were no projects. Similarly in Table 2, development of multi-family projects fluctuated from year to year. The April meeting was the conclusion of the PRBC hearings as the next scheduled meeting was a special joint meeting with the City Council and PRBC.

City Council Hearing

The special joint hearing with the City Council and PRBC was conducted on May 1,2014 . The primary purpose of this meeting was to present the work done toward the Public Art Program. Here, the PRBC, in conjunction with City Staff, presented the draft program to the City Council. The presentation outlined all the necessary components, including funding and review options. The goal of this meeting was to get final direction on alternatives from the Council and see if 
they would like to pursue the implementation of a formal program. The majority of the discussion during the hearing was in regards to appropriate funding sources. The Council appeared to be divided on if public art should be funded by the City or private developers. Ultimately, Council decided to consider the incorporation of public funds at the upcoming annual budget session meeting in June. The City Council was very pleased with the work that had been completed towards this project and was excited about its potential. They directed City Staff to follow up with the City Attorney regarding legalities on imposing exactions and if the review outlined is appropriate, pursuant to the Brown Act. Ultimately, they expressed consensual interest in the implementation of the Public Art Program.

\section{Public Outreach}

Public outreach is a critical component of planning practice. It is irrational for planners to assume they are knowledgeable experts to a community, therefore outreach is needed to allow the community to voice their concerns. The City of Pismo Beach was currently undertaking a downtown vision plan that included public art as a discussion point. As part of the outreach efforts for the visioning plan, a workshop was held, in which the Public Art Program concept was able to be a

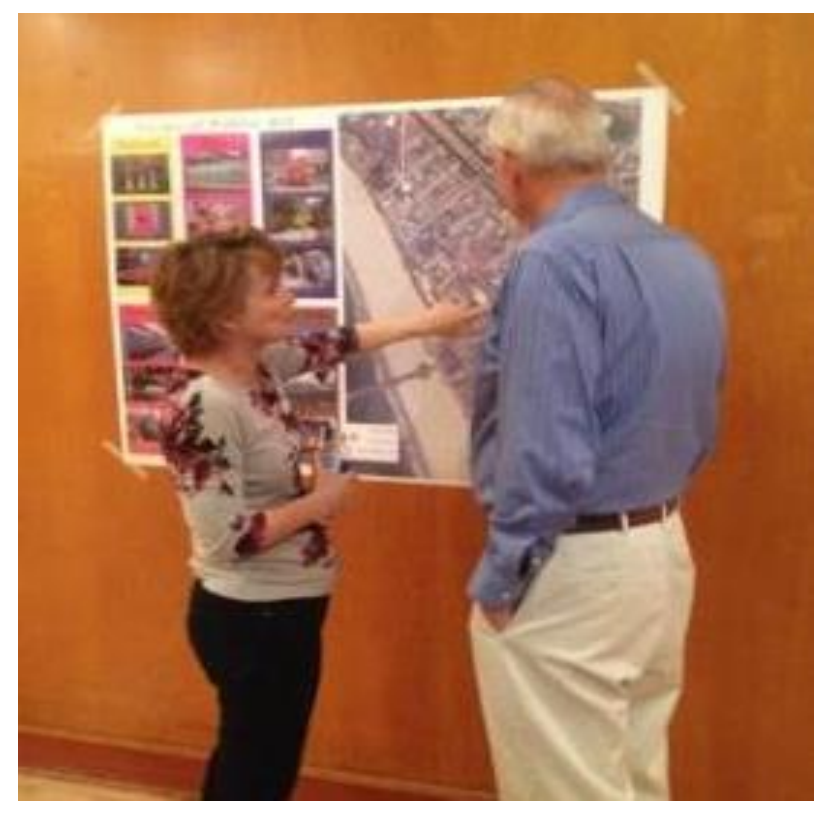

Figure 12 - Participation in Outreach Exercise 
component of the discussion. The exercise for the Public Art Program (Figure 12) included a large poster board with forms of public art on one side and the recommended downtown locations for public art from the PRBC on the other side. The public was directed to place red and green dots on the poster board. The red dots were signified for types of public art they didn't like and the green dots were for types of public art they did like. Figure 13 illustrates the results of the participation efforts during the exercise. The majority of the community responded well to all forms of public art. Specifically, they responded best to sculptures, public works, and gateway forms. This information allows City Staff and the PRBC to get a general understanding of which public art forms may be accepted in the future. Table 3 lists five key locations in Pismo Beach that can be

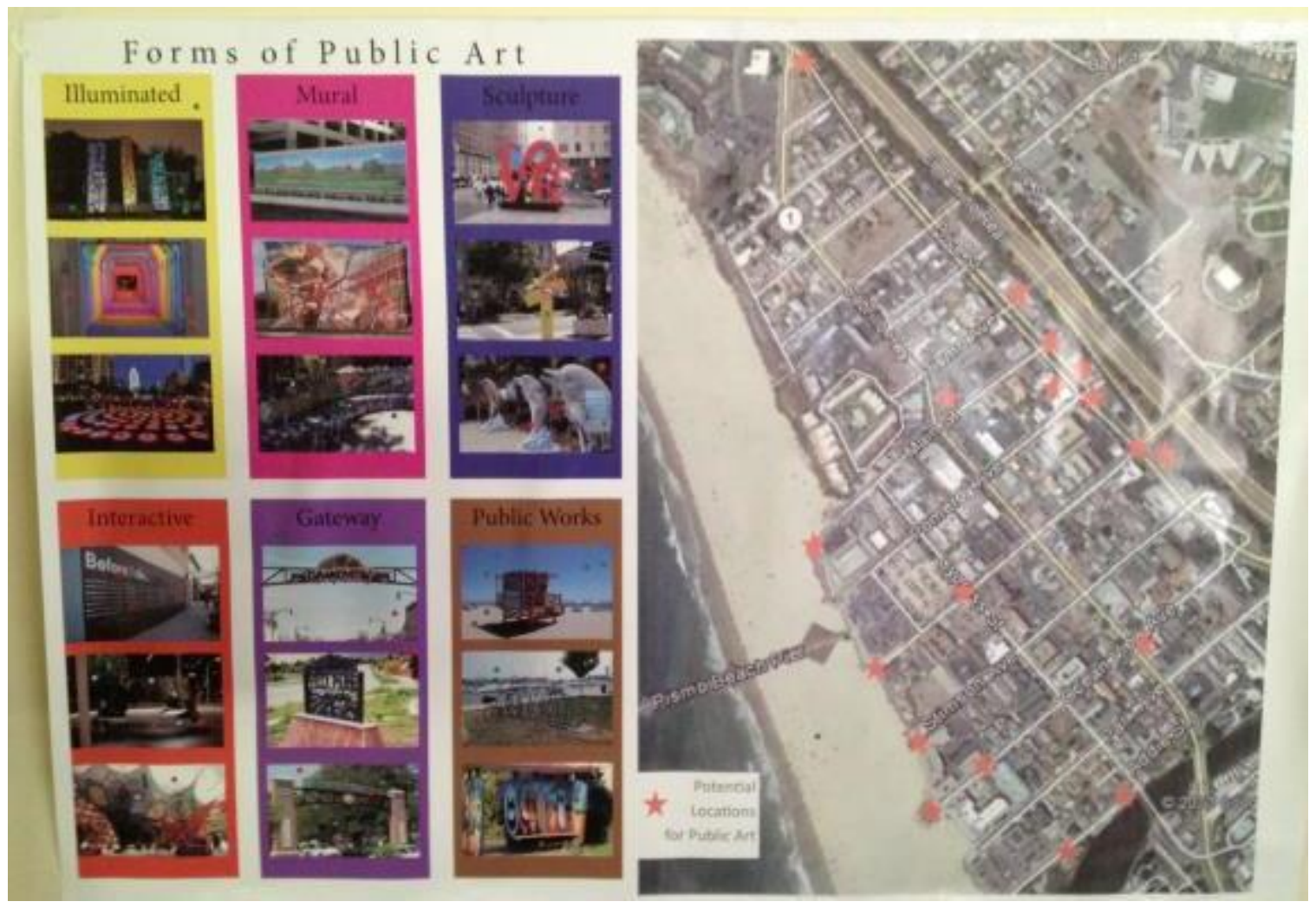

Figure 13 - Results of Outreach Exercise 
considered high value sites and may be seen as the most important locations to implement public art as projects arise. These locations are both on public and private properties, which should be secured for the incorporation of public art. In addition to the workshop, the Seaside Gallery provided input on the Public Art Program. The Seaside Gallery is a local art exhibit in downtown Pismo Beach. They are considered a stakeholder who has an interest in the implementation of the Public Art Program. They were in attendance of the majority of the PRBC hearings, including the City Council hearing, who addressed City Staff and the Commission with recommendations. For example, it was suggested that when establishing funding for public art, it is critical that the monies are in a separate fund that may not be touched for other city projects. This ensures that the monies will be entirely used on implementation and maintenance of public art and public art related activities. Additionally, it was recommended to pursue temporary art exhibits in Pismo Beach as a means to generate revenue for the program. Examples of this come from Grand Junction, Colorado, where the City allows artists to temporarily display and sell their artwork for a period of time. In addition, the idea of generating some form of exhibit utilizing the beach, like sand sculptures contests, were also brought into conversation as a way to generate revenue. It is important to note that public art is a way to attract tourism, which is a huge economic revenue source for cities, therefore incorporating events can contribute to the success of a public art program. 
Case Study Review

The review of cities with public art ordinances or programs was an important part of the development of the Pismo Beach Public Art Program. The research and suggestions gathered from the analyzed cities was provided during the PRBC hearings as supporting information of how programs are operated in other municipalities. The City of Capitola has a public art ordinance that utilized exactions to help support the funding of their public art. One major consideration about public art is maintenance. In correspondence with the City of Capitola, it was suggested to set aside roughly $\$ 5,000$ per year for the maintenance of publicly owned artwork. Currently, they are maintaining five pieces of public art. Other city discussions included how much should be anticipated for the payment of artwork. It was learned that public art can vary in costs. Some sculptures can cost upward of $\$ 20,000$ while others are merely $\$ 2,000$. So when determining the amount of money Pismo Beach would like to collect in exactions or support using

Table 3 - Key Locations for Public Art

\begin{tabular}{|l|c|}
\hline \multicolumn{1}{|c|}{ Locations for Public Art } & $\begin{array}{c}\text { Level of Importance } \\
\mathbf{1}=\text { highest } \\
\mathbf{3}=\text { lowest }\end{array}$ \\
\hline $\begin{array}{l}\text { Ocean overlooks: end of Main Street, Pomeroy } \\
\text { Avenue, Hinds Avenue, Stimson Avenue, Ocean } \\
\text { View Avenue }\end{array}$ & 2 \\
\hline Intersection of Highway 1 and Addie Street & 2 \\
\hline Intersection of Highway 1 and Price Street & 1 \\
\hline Parks: Palisades, Seacliff, Chumash, Boosinger & 3 \\
\hline Pismo Beach Pier/Promenade & 1 \\
\hline
\end{tabular}


their own existing funding sources, determines the type of art they want to obtain. In essence, good art comes with a hefty price tag.

Reviewing the Cities of Palm Springs, Encinitas, and Dana Point, was to merely look at their ordinance to see their funding mechanism and review procedure, as these were the most negotiated topics at the PRBC hearings. It was learned some cities do not utilize exactions to support their programs, while others do. Additionally, some cities pose impact fees on single-family residences, but at a much lower cost. For review procedures, many of the cities have established some form of a public art committee that is responsible for the initiation and review of public art. It is important to understand that all cities operate slightly different because of their population size, the amount of money they generate annually, and available staff time. These case studies provided a good base on what is commonly seen in the structure of public art program, but they do not exemplify best practice. Best practice in conceived by the bounds of the city's budget, available commitment of staff time, and overall acceptance from the public and political officials.

Implications of Findings

The PRBC was the most influential group in the development of the Public Art Program. Their influence was through directing City Staff based on their discretion of how the program should operate. City Staff's role was to essentially present the facts of how programs are operated elsewhere, provide information regarding the city's budget, and other information deemed necessary by Staff or direction from the Commission. 
One implication results from an impact fee. If the City were to pursue an exaction on single-family homes, the potential revenue source would increase dramatically. The majority of building permits in Pismo Beach are single-family residences that well exceed $\$ 250,000$. Both the PRBC and City Council were not in support of creating an exaction on single-family projects. Another implication to the collection of in-lieu fees, as shown in Tables 1 and 2, is the lack of a predictable revenue stream. As a result, the City could allocate a small percentage of existing city revenue sources such as, the general fund, transient occupancy tax, parking meters, sales tax, or the creation of a separate tax. An example of the separate special tax is demonstrated in Mammoth, California, where the Town created a Tourism Business Improvement District (TBID) tax that charged an extra fee onto tourism related businesses. Typical businesses include lodging facilities, restaurants, and gift shops.

Public art maintenance can be a constraint to many programs. It is important that the City sets up a structured formal agreement or contract between the artist and developer that decides who maintains the art, how often, and for how long. Since Pismo Beach is a coastal community, there are more maintenance issues that must be considered from the potential corrosion due to the salty air. Other maintenance considerations are vandalism, fading from the sun, and complete wreckage. The maintenance agreement will be a subcomponent to the application for public art, subject to approval from the City Attorney. The maintenance agreement is not provided as part of this Public Art Program. 
The City Council is the ultimate decision maker in the operation of the Public Art Program. The Council expressed an interest in utilizing existing city revenue sources rather than adopting another impact fee, as they felt public art is more of a responsibility to the City, rather than individual developers, however, there was not a full consensus on this, as other councilmembers were in favor of impact fees. Ultimately, the final decision from City Council will not be conducted until after additional meetings. The Pismo Beach Public Art Program in Appendix A was developed based on the primary feedback given from the PRBC, as further continuation to the City Council still needs to be completed.

The City of Pismo Beach Public Art Program is a result of the direction given from the PRBC, City Council, City Staff, the public, and stakeholders. The Public Art Program utilizes the best techniques suitable to the City of Pismo Beach, based on the implications outlined in this chapter. 
Bibliography

AIDS Quilt Comes to Forks. (n.d.) [Photograph]. Retrieved from http://forkswa.com/2010/02/27/aids-quilt-comes-to-forks/

Banerjee, T. (2007). The Future of Public Space: Beyond Invented Streets and Reinvented Places. Journal of the American Planning Association, 9-24.

Beardsley, J. (1981). Art in Public Places. Washington DC: Partners for Livable Places.

Becker, J. (2004, March). Public Art: An Essential Component of. Retrieved from http://www.americansforthearts.org/pdf/networks/pan/becker_communities .pdf

Bogart, \& H., M. (2006). The Politics of Urban Beauty. Chicago: The University of Chicago.

City of Capitola. (n.d.). Art \& Cultural Commission Events. Retrieved from http://www.cityofcapitola.org/acc/page/art-cultural-commission-events

City of Dana Point. (n.d.). Art In Public Places. Retrieved from http://www.danapoint.org/index.aspx?page $=128$

City of Encinitas. (n.d.). Arts. Retrieved from http://www.ci.encinitas.ca.us/index.aspx?page $=127$

City of Palm Springs. (n.d.). Public Art. Retrieved from http://www.palmspringsca.gov/index.aspx?page $=1185$

Civic Center. (n.d.) [Photograph]. Retrieved from http://beforeidie.cc/walls/neworleans-usa.html

Danny. (2013, July 20). Banpo Bridge Seoul Rainbow Fountain Show [Photograph]. Retrieved from http://www.worldofdesigners.com/banpo-bridge-seoul-rainbow-fountainshow/

Eccentric Roadside (2011, October 1) [Photograph]. Retrieved from http://eccentricroadside.blogspot.com/2011/10/well-here-we-are-pismobeach-and-all.html

Fleming, R. (2007). The Art of Placemaking. New York: Merrell.

Fleming, R., \& Tscharner, R. v. (1987). Placemakers. Boston: Harcourt Brace Jovanovich. 
Galis, L. (2012, March 27). Galis: Public art does bring public benefits. Retrieved from http://onlineathens.com/opinion/2012-03-27/galis-public-art-does-bringpublic-benefits

Goldstein, B. (2005). Public Art by the Book. Seattle: Americans for the Arts; University of Washington Press.

Green, J. (2011, April 20). The Many Benefits of Public Art. Retrieved from http://dirt.asla.org/2011/04/20/the-many-benefits-of-public-art/

Hall, P. (2002). Cities of Tomorrow. Malden: Blackwell Publishers Ltd.

Jobson, C. (2012, September 13). Musical Light Swings on the Streets of Montreal [Photograph]. Retrieved from http://www.thisiscolossal.com/2012/09/musical-swings-on-the-streets-ofmontreal/

Miles, M. (1997). Art, Space and the City. London: Routledge.

National Endowment for the Arts. (2013). National Endowment for the Arts Releases Funding Guidelines for Our Town. Retrieved from http://arts.gov/news/2013/national-endowment-arts-releases-fundingguidelines-our-town

Project for Public Spaces. (2009, January 1). Public Art. Retrieved from http://www.pps.org/blog/public-art/

Project for Public Spaces. (n.d.). Funding Sources for Public Art. Retrieved from http://www.pps.org/reference/artfunding/

Public Art Network Council: Green paper. (n.d.). Retrieved from http://blog.artsusa.org/artsblog/wpcontent/uploads/greenpapers/documents/PublicArtNetwork_GreenPaper.p df

Raven, A. (1989). Art in the Public Interest. Ann Arbor: UMI Research Press.

The Lakewood Observer. (n.d.). Lakewood is Art.Com. Retrieved from http://lakewoodisart.com/public-art/why-public-art/ 
U. S. Census Bureau. (2012). American FactFinder fact sheet: Pismo Beach, CA. Retrieved February20, 2014, from

http://factfinder2.census.gov/faces/tableservices/jsf/pages/productview.xht ml?pid=ACS_12_5YR_S0101\&prodType=table

We Waste Time (n.d.). Retrieved from http://wewastetime.com/

Weiser, I. (2004, July 8). Benefits of public art far outweigh the costs. Retrieved from http://seattletimes.com/html/opinion/2001974123_weiser08.html

Wikipedia. (n.d.). Minneapolis Sculpture Garden [Photograph]. Retrieved from http://en.wikipedia.org/wiki/File:Spoonbridge_and_Cherry_summer_and_w inter2.JPG 


\section{Appendix A: Pismo Beach Public Art Program}




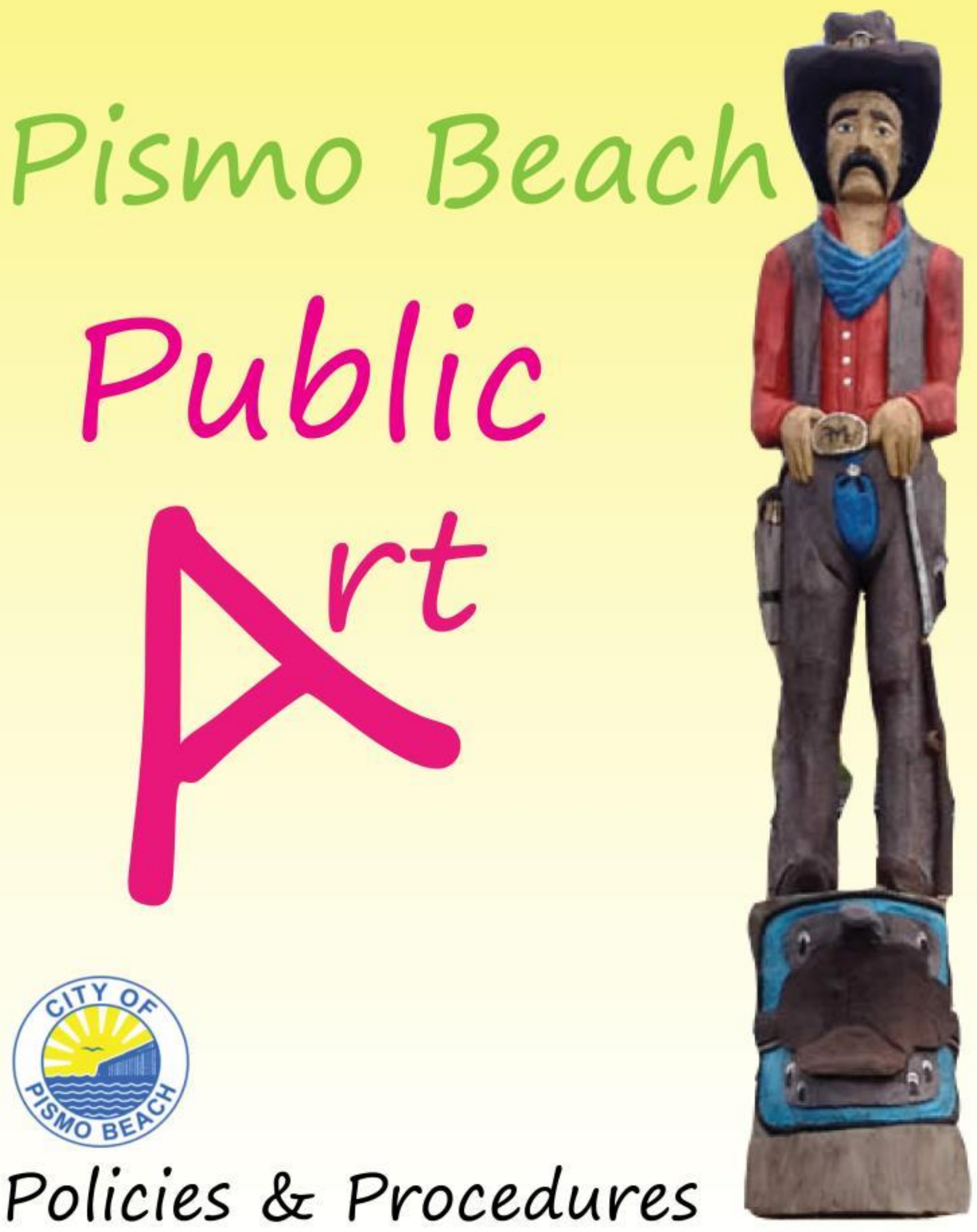




\section{Pismo Beach and Public Art}

The Pismo Beach Public Art Program is a means to incorporate art within new and existing developments or publicly owned spaces for public enjoyment.

Pismo Beach strives to preserve its character for the best possible environment for residents and visitors. Aesthetic enhancement to public places can provide a substantial economic benefit while improving the well-being of the community. Pismo Beach is home to a richly diverse and talented arts community, whose City's artistic reputation is vital to its residents, who view their town as more than a collection of roads and buildings, but as a concentration of cultures and ideas. Public art in Pismo Beach has the opportunity to become a memorable moment in time, where such iconic art pieces can be captured in pictures, postcards, and family photo albums. Public Art can complement the Pismo Beach Classic California character and visual experience while enhancing the City's capacity to become a world renowned tourist destination.

\section{Classification of Public Art}

Public art can be defined as the engagement of an artist with a public place involving original, creative work by an individual or a group. Public art can be functional and include capital improvements such as seating, fountains, lighting, and public improvements as well as free standing art forms. Public art may also include, but will not be limited to:

- Sculpture; such as in the round, bas-relief, mobile, fountain, kinetic, electronic, or other, in any material or combination of materials such as sand and water;

- Painting; all media, including but not limited to, murals;

- Graphic and multi-media; printmaking, drawing, calligraphy and photography including digital, any combination of forms of electronic media including sound, film, holographic, and video and other art forms but only when on a large public scale;

- Mosaics on horizontal and vertical surfaces;

- Illuminated and/or interactive art;

- Crafts; in clay, fiber and textiles, wood metal, plastics and other materials;

- Mixed media;: any combination of forms or media, including collage;

- Any other art form determined appropriate by the City Council. 


\section{Locations for Public Art}

Through this program, public art may be located in a city owned public place, including, but not limited to parks, public rights of way, plazas or pedestrian walking areas, parking facilities, trail areas, beach access areas, the public pier, the grounds of City owned buildings or structures, or other city owned property. Public art may also be located on private development within view from the public right of way.

\section{Funding and Development Requirements for Public Art}

Participation in the Public Art Program is required for public and private construction projects, excluding single-family residential, where expansion of, remodeling of, or tenant improvements to existing eligible buildings that have a total building permit valuation of two hundred and fifty thousand dollars or more.

\section{Privately Funded Development}

All commercial, multi-family residential (exceeding 3 units), and new single-family subdivision tract projects, whose total building permit valuation exceed $\$ 250,000$ are obligated to contribute to the Public Art Program. The project applicant may contribute funding in two ways:

1. The applicant is required to provide public art that costs no less than $1 \%$ of the total building permit valuation. Incorporation of public art on the eligible project shall be within the public's view.

2. The applicant may request a waiver of the requirement for installation of public art from a project with payment of an in-lieu fee of no less than $2 \%$ of the total building permit valuation. Waiver of the requirements will be subject to approval from the City Council. Should the City Council authorize the use of an in-lieu fee instead of the installation of public art with the approved project, the in-lieu fee would be made to the City prior to the issuance of a building permit for the project.

Funds collected as in-lieu will be used for the creation, installation, and/or maintenance of city initiated public art projects. 


\section{Publicly Funded Development}

For public projects, the City Council would provide in the capital project budget an amount of not less than $1 \%$ of the total amount budgeted for each "eligible construction project" for acquisition and installation of works of art within the vicinity of the subject capital project.

The City Council may, at any time, provide additional revenue sources from existing capital. When considering these types of funding sources, an evaluation is necessary to determine if/how the use of the funds from these sources for public art could impact the purposes for which they are normally designated.

The City may actively pursue other sources of funding as deemed necessary. Other sources of funding include, but are not limited to:

- Donations from endowments

- Revenue specifically targeted from fees charged to hold large events/festivals

- Foundation Grants

- Other programs - The City of Pismo Beach may consider displaying public art downtown on a rotating loan basis.

\section{Review Process for Public Art}

For privately funded projects, applicants will follow the public art review process outlined in items 1 through 5.

For publicly funded projects, the Parks, Recreation and Beautification Commission will initiate the review process and follow the process outlined in items 1 and 3 through 5.

Flow charts summarizing the process for both private and public funded projects are provided as Exhibits 1 and 2 .

\section{Submittal to Community Development Department}

The proposal concept shall be submitted to the Community Development Department. The proposal concept shall include an application form (Exhibit 3) with:

- The artist name 
- General concept of the art piece identified by a description and draft rendering of the proposed art piece such as a photograph, artist's rendering, or computer generated image.

- The maintenance requirements and estimated maintenance costs on an annual basis.

- The materials and size of the work

- The proposed location

- The artist's resume if available

- Estimated value of artwork

\section{Parks, Recreation and Beautification Commission (PRBC) Concept Review}

\section{(publicly funded/initiated projects skip this step)}

For each project, the PRBC will review the public art concept considering its form, relationship to the proposed space where it will be located, and its scale. If the concept is not approved, the applicant will have to modify or create a new proposal and resubmit an application. If the PRBC approves the concept, the proposal will continue through the process.

\section{City Staff Review}

City Staff review will entail an assessment of the concept against the City's Zoning Ordinance, General Plan, Building and Fire Code codes, and Risk Management requirements to:

- Insure it will not create an undue risk or a safety problem

- Consider maintenance requirements

- Determine durability

- Identify any engineering concerns

\section{Parks, Recreation and Beautification Commission (PRBC) Public Hearing Review}

Following City Staff review and at the next available PRBC meeting, the Commission will select an ad hoc group of three individuals from the community to assist them in the public hearing for review of the art proposal. These three individuals may include local artists and / or Pismo Beach residents or Pismo Beach property owners. The three individuals are selected by the PRBC after a one time one-eighth page public advertisement. The PRBC may request San Luis Obispo Arts Council assist the Commission by identifying potential artists for 
consideration. The ad hoc group can change after each proposal, depending upon the location and type of art proposed.

At a following public hearing, the PRBC and the selected ad hoc group will review the Public Art proposal. The review will include, if applicable, the base on which the art piece will be located in context with the artwork, the art piece and the plaque that will be created to identify the artwork. Collectively the PRBC and ad hoc committee review the proposal based on the following guidelines:

- Originality and high artistic quality.

- Reflection of the character of the area where the art piece would be placed.

- Be complementary to the immediate site and neighborhood in terms of social and cultural/historical characteristics, architectural scale, materials, land use, and geographical and environmental context.

- Consideration of a broad variety of artist's designs, expressions, and interpretations.

- The artwork could not impede pedestrian, bicycle, or vehicular traffic.

- Public safety and health would not be compromised by the public art or its installation.

- The public art would need to be comprised of durable, high quality materials and require minimal maintenance.

- Expressions of profanity, vulgarity, advertisement (including logos), political, religious, or philosophic persuasions will not be permitted.

- The public art must be visually accessible for public enjoyment.

Following PRBC and its ad hoc committee review, a recommendation on whether the public art is appropriate will be formulated for the City Council for final action.

\section{City Council Review and Action}

The PRBC and ad hoc committee recommendations will be forwarded to the City Council at the next available public hearing. The City Council will review the recommendation made by the PRBC and make a final decision to approve, deny, or provide more direction on the proposal.

\section{Implementing Public Art after City Council Approval}

The following 5 steps outline the implementation stages of public art, after completion of the review process. The 5 steps apply to both private and publicly funded projects. 


\section{Contract}

A contract between the artist and the City establishing the terms of the proposed installation is required. If a design is altered after the artwork is accepted, it will be considered a new art piece, requiring compliance with the processing noted in this program.

\section{Art Identification}

Labeling of the artwork that includes the artwork title, artist's name, patron's name if applicable, and date of completion is required. The materials used and a short explanation of the work may be included as an option. Plaques may not be used for advertising purposes.

\section{Maintenance, Installation, and Removal Information}

Private Projects - Prior to accepting the project, the Public Works Department will need from the artist or donor a set of plans, specifications, and a copy of a maintenance record which identifies maintenance, potential maintenance costs, installation, and removal instructions and costs. The transportation, installation, and adjunct costs (such as engineering, a base for the artwork or other installation elements) related to artwork is the responsibility of the applicant. The applicant shall be required to install the artwork, they shall be required to indemnify the City from any responsibility for damage to the artwork, and must accept responsibility for any damage to city property due to the act of installing the artwork.

Public Projects - The Public Works Department will secure from the artist a set of plans, specifications, and a copy of a maintenance record which identifies maintenance, potential maintenance costs, installation, and removal instructions and costs. The transportation, installation, and adjunct costs (such as engineering, a base for the artwork or other installation elements) is the responsibility of the City.

\section{Safety Inspection}

Once the art piece is installed, (by the applicant under the supervision of city staff with the artist's installation direction and applicant installation funding) an inspection and sign off by a City Building Official if located on private property, or the City Engineer if located on public property, is required. 


\section{Dedication Ceremony}

Following the inspection, a publicized dedication ceremony will be held and the art piece will be presented to the Community.

\section{Maintenance of Artwork on Public and Private Property}

Public artwork on public property - Monies will be set aside from the art in-lieu fee for the maintenance of public artwork. Specific instructions for care of each work shall be kept on file and be submitted as part of the project application. The PRBC will include maintenance provisions in the artwork contracts stipulating the length of time (typically one year). Artists who are stipulated to be solely responsible for repairs are required to provide a maintenance manual. Artists have first refusal on repair contracts within a fair market rate of remuneration. Regular inspections for condition reporting shall be conducted so that the collection is maintained in the best possible condition.

Private artwork on private property - The obligation to provide all maintenance necessary to preserve the artwork in good condition shall remain with the owner of the site. Art installed on or integrated into a construction project, pursuant to the provisions of this Program, shall not be removed or altered without the approval of the PRBC. A written agreement between the City and the private property owner shall be specified regarding the artwork. Maintenance shall include without limitation, the preservation of the artwork in good condition to the satisfaction of the City and protection against physical defacement, mutilation or alteration. If the artwork is not maintained in the manner prescribed or is removed or altered without approval of the PRBC, in addition to all other remedies provided by law, the City may, upon reasonable notice, perform all necessary repairs, maintenance, or take such legal or other action deemed necessary to have the artwork maintained and if necessary, restored, and the cost therefore shall become a lien against the real property. 


\section{Exhibit 1}

Private Development

Pismo Beach Public Art Program Review Process

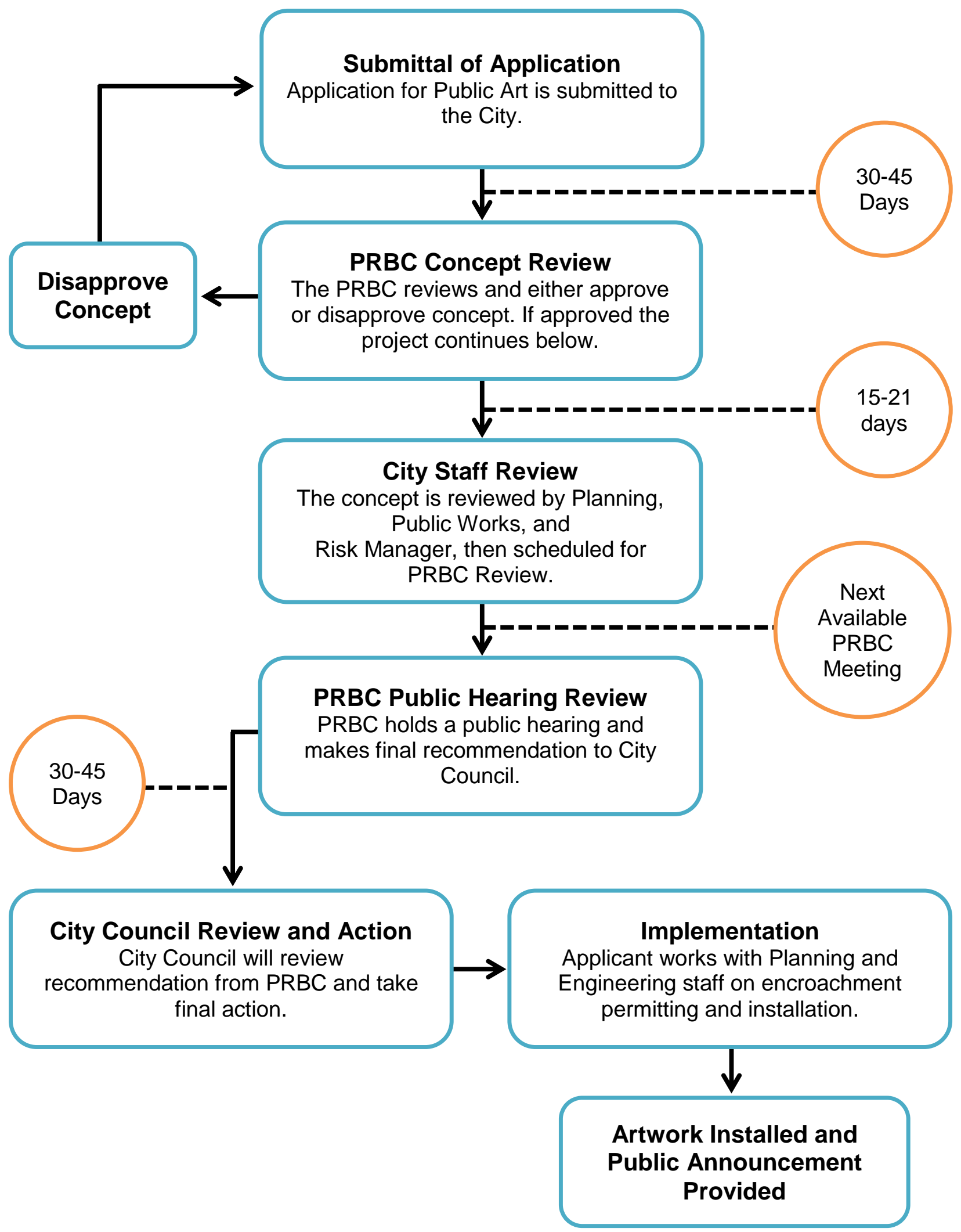




\section{Exhibit 2}

Publicly Funded/Initiated Projects

Pismo Beach Public Art Program Review Process

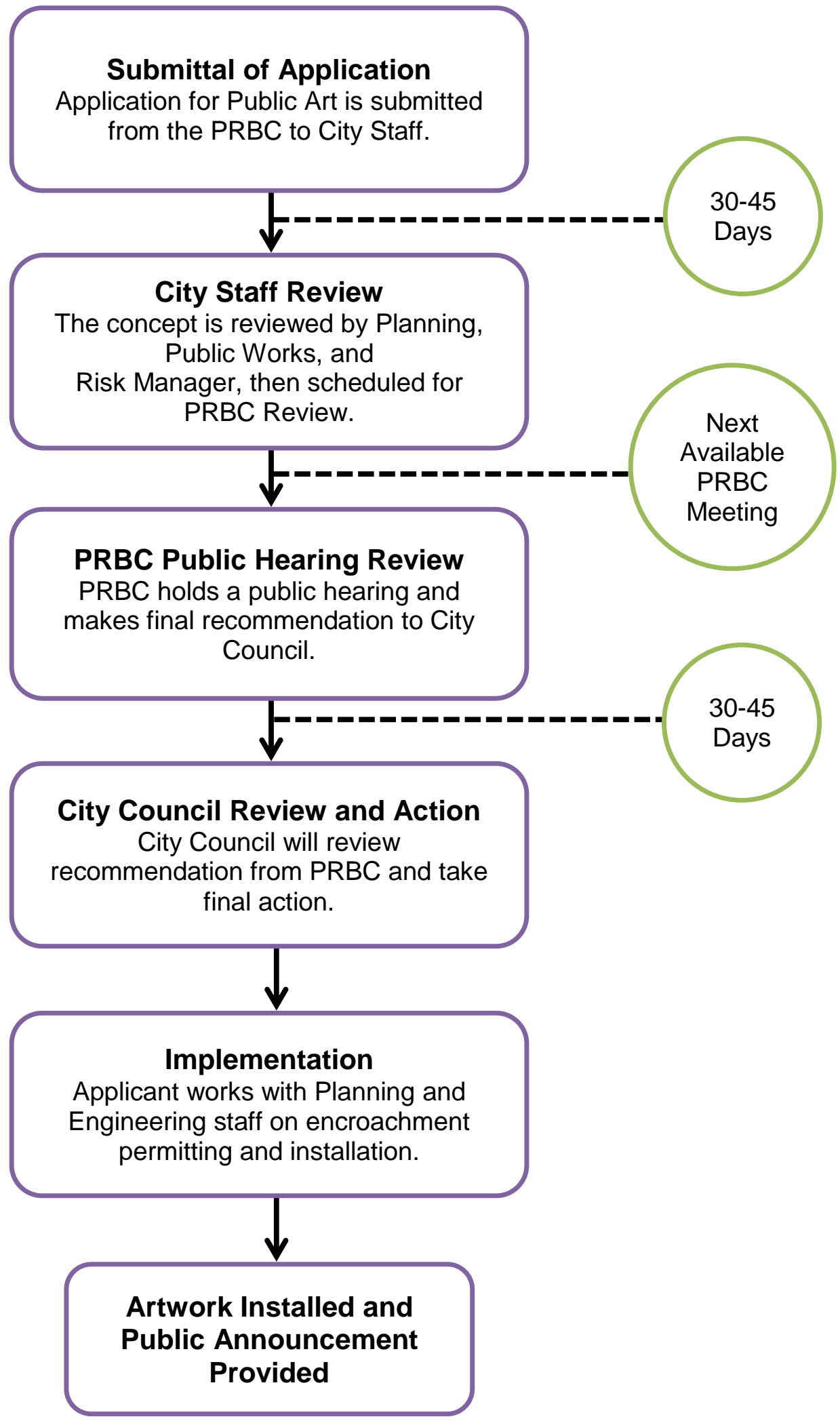




\section{Exhibit 3}

\section{Pismo Beach Public Art Program Application Form}

The applicant must complete and sign this application form. If the applicant is not the artist who created the artwork, the artist must also sign this application below.

Applicant (Name, address and phone number)

Title of Artwork

Description of Artwork (attach drawings or photographs or other graphic depiction)

Materials/Size

Proposed location (inside or outside, location should be specific, for example, "at the entry of xyz park, or on the northwest corner of $x$ street and $y$ street)

Maintenance Requirements and estimated potential yearly maintenance costs 
An appraisal or other evidence of the Value of the proposed public artwork

By signing this application below and in consideration for participating in the City's Public art program, the artist/owner hereby acknowledges and assigns the right to the City to collect any royalty payment provided by Civil Code section 986. Except as provided above, the artist/owner further acknowledges and waives, for himself and his successors in interest, to the greatest extent allowed by law, any rights the artist/owner may have under California Civil Code sections 986, 987, 988 and 989 , or other applicable law.

The artist/owner further acknowledges and understands that upon completion and installation of artwork, and upon its acceptance by the City Council, the work shall become the property of the City without any right of reversion in the artist/owner. The City retains the right to remove or relocate the artwork in its sole discretion, as the interest of the public welfare, health and safety may be required.

If the owner/artist installs the artwork, the owner/artist acknowledges that the City is not responsible for any damage to the artwork, to the property on which the artwork is installed, or for any other damages in any way related to the installation of the artwork. The owner/artist accepts responsibility for all damages resulting in any manner from the owner/artist's installation of the artwork, and agrees to indemnify and hold the City, its elected and appointed officials, officers, employees and agents harmless against any claims for damages of whatever description resulting from or allegedly resulting from the owner/artist installation of the artwork.

If the artwork is damaged, defaced, altered or destroyed by human acts, by acts of nature or otherwise, the City retains the right to remove, restore, repair or replace the artwork at any time in keeping with the artist's original design intent, without consulting the artist, or his or her heirs or assigns. The City will make reasonable efforts to contact the artist, or if unavailable, another design professional, to advise or assist in any restoration work. 
The artist/owner agrees to an alternate site should the City Council determine a more appropriate location.

I have read, understood and accept the terms of this Application and represent that I am the of the artwork, which is the subject of this application.

(Owner, artist, or owner and artist)

Date:

Signature

Print name

I have read, understood and accept the terms of this Application and represent that I am the of the artwork, which is the subject of this application.

(Owner, artist, or owner and artist)

Date:

Signature

Print name 
Appendix B: Local Art Brochure 
Art Grows in Pismo Beach!

Enjoy, Discover \& Embrace Local Art opportunities in Pismo Beach! See map below for art locations on pablin \& private properties throughout the City.

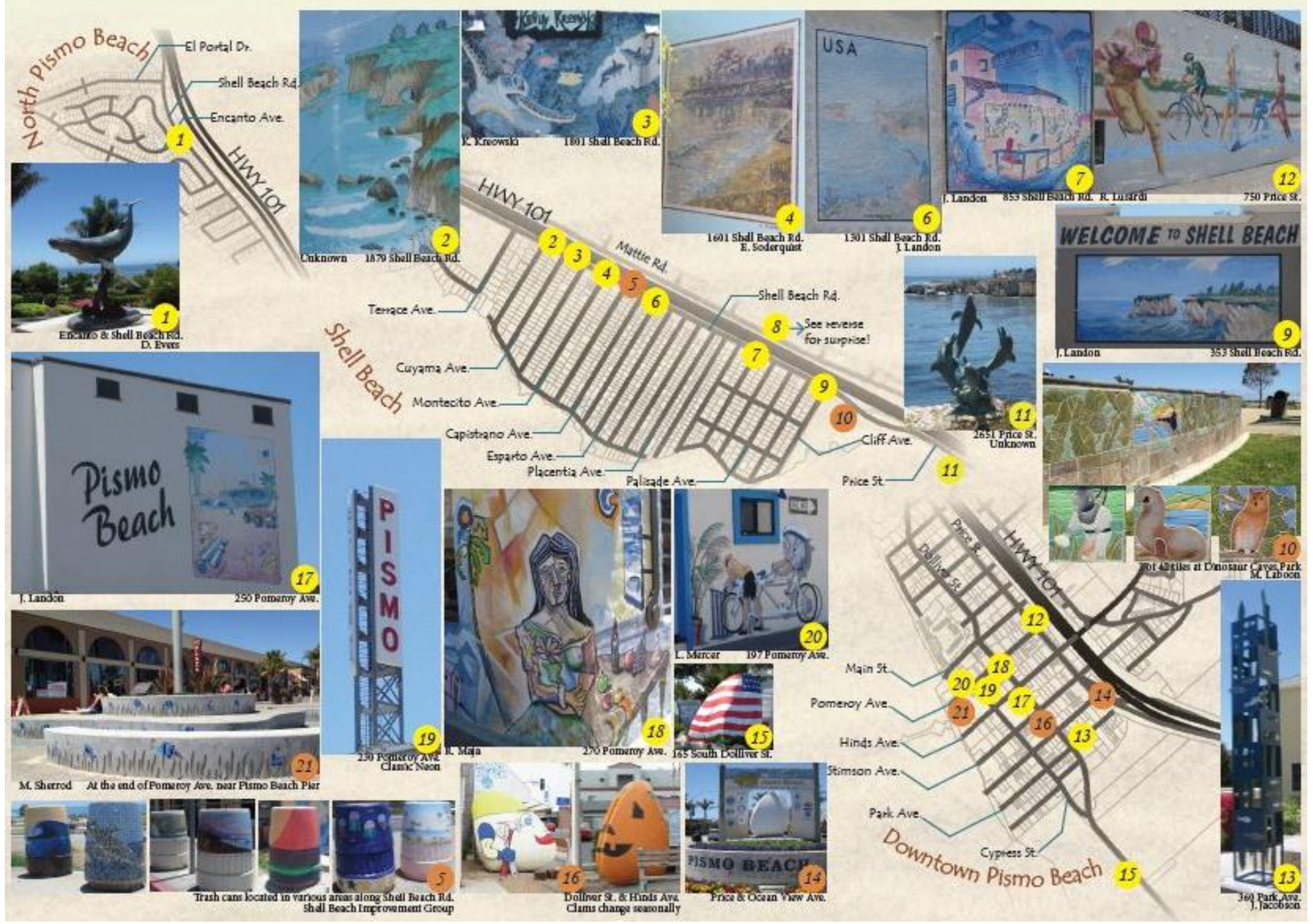

